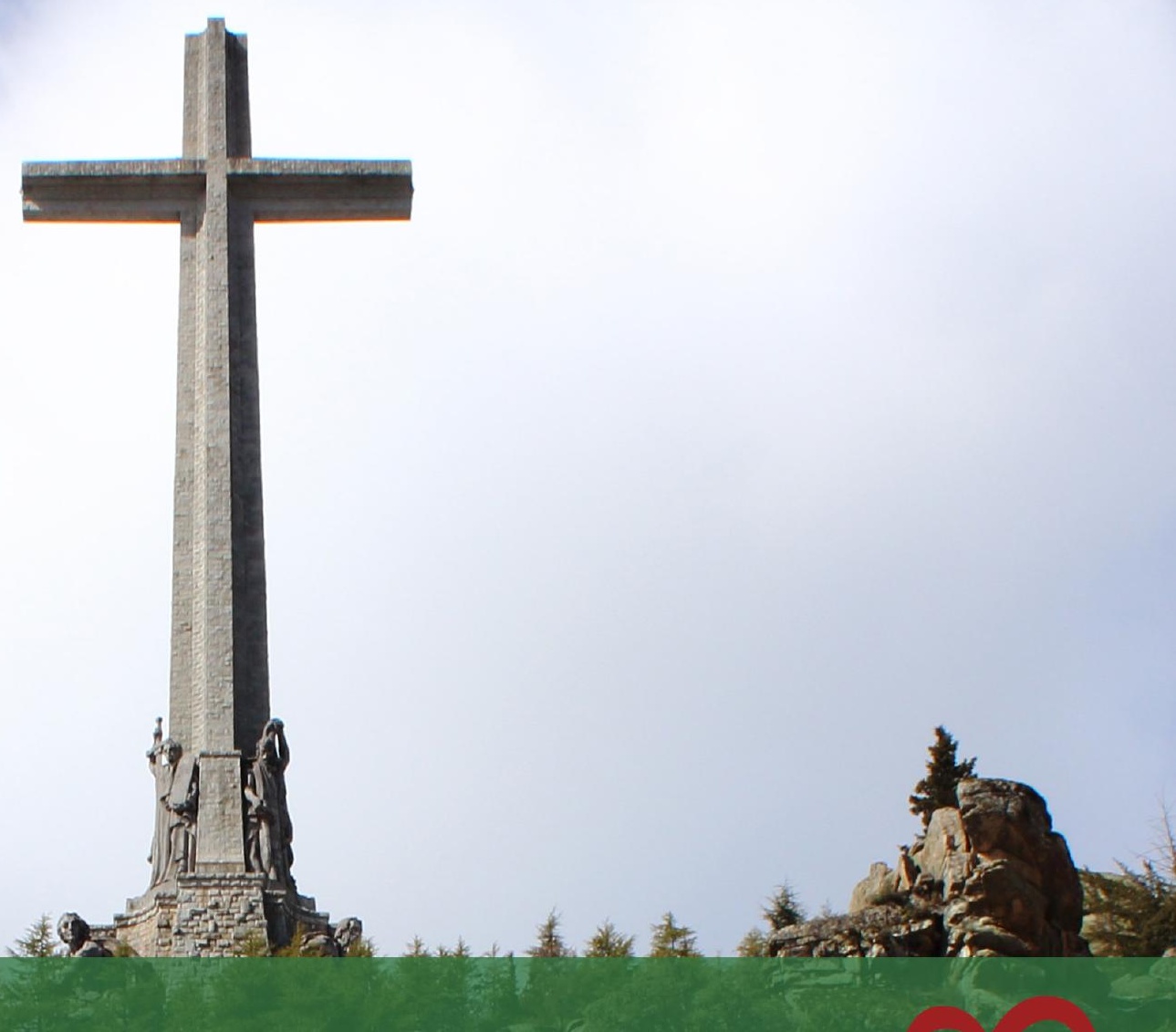

Revista digital de Ciencia y Didáctica de la Historia

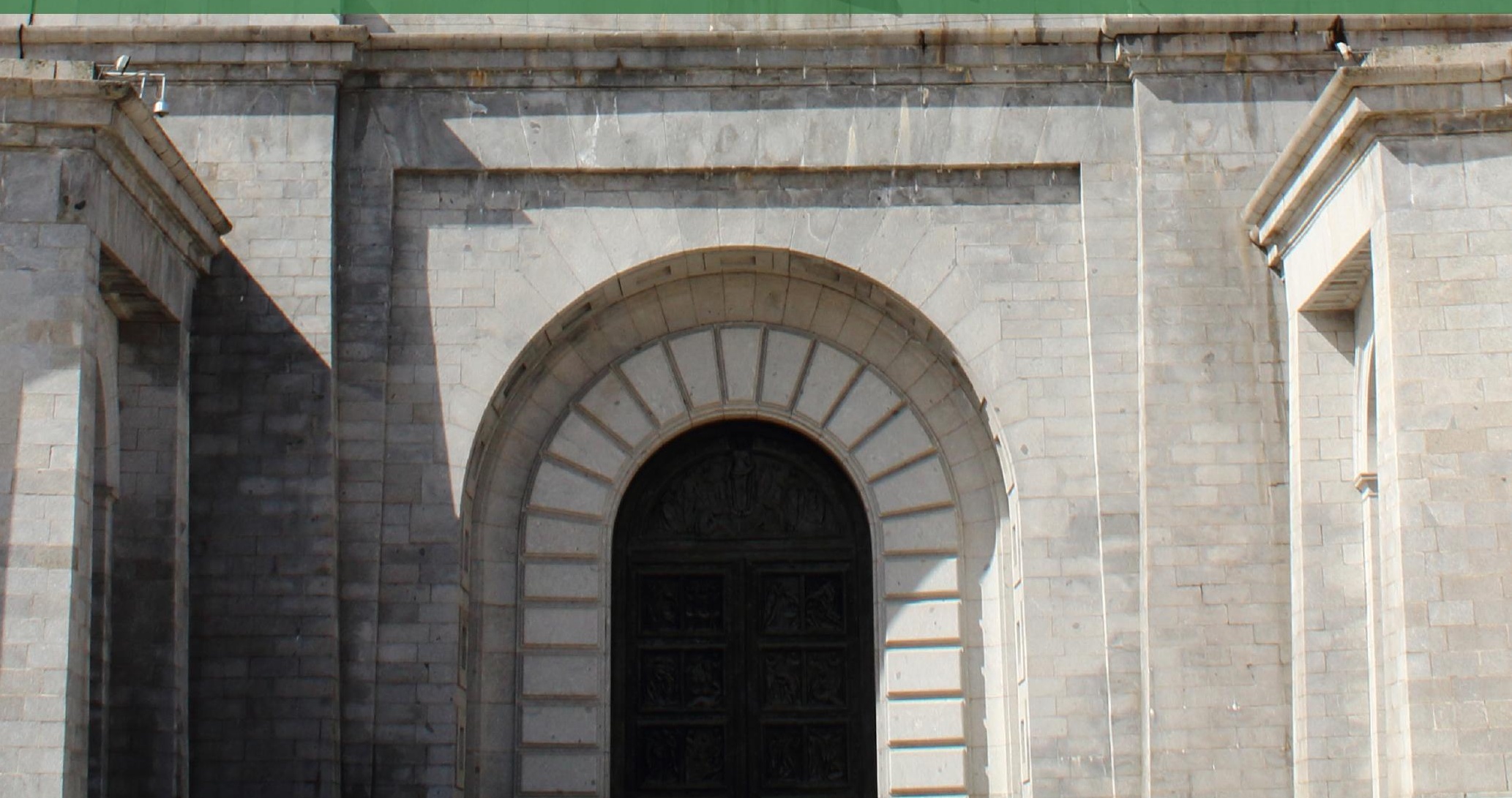




\section{Panta Rei \\ Revista Digital de Ciencia \\ y Didáctica de la Historia}

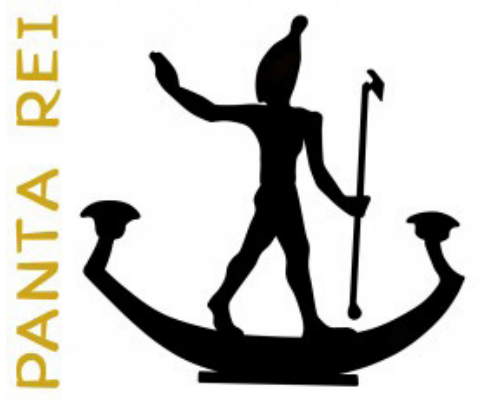

\section{8}

Revista anual

Fecha de inicio: 1995

Revista Panta Rei. pantarei@um.es

Edita:

Centro de Estudios del Próximo Oriente y la Antigüedad Tardía - CEPOAT

Edificio Universitario Saavedra Fajardo.

Universidad de Murcia

C/ Actor Isidoro Máiquez, 9

30007 - MURCIA - ESPAÑA

Teléfono: (+34) 868883890

cepoat@um.es

Web: www.um.es/cepoat/pantarei

Edición 2018

ISSNe: 2386-8864

ISSN: 1136-2464

Depósito legal: MU-966-1995

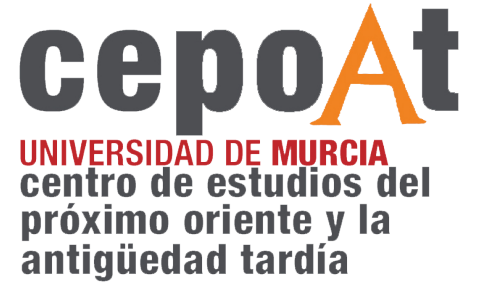

En Portada: Valle de los Caídos, Madrid. (Fotografía de: Adrián Rosell Lucas).

Responsables de los textos: Sus autores.

Responsable de la presente edición: Consejo Editorial Panta Rei. 


\section{CONSEJO DE REDACCIÓN}

\section{Coordinador editorial}

Egea Vivancos, Alejandro

[Didáctica de las Ciencias Sociales, UMU]

\section{Editores}

Botí Hernández, Juan Jesús

[CEPOAT, UMU]

Jiménez Vialás, Helena

[UMU]

López Muñoz, Damaris

[UJA]

Meseguer Gil, Antonio José

[CEPOAT, UNED]

Sáez Giménez, David Omar

[CEPOAT, UMU]

Sánchez Mondéjar, Celso Miguel

[Patrimonio Inteligente]

\section{Secretaria}

Arias Ferrer, Laura

[Didáctica de las Ciencias Sociales, UMU]

\section{Responsable informático}

Martínez García, José Javier

[CEPOAT, UMU]

\section{Traducción y corrección lingüística}

Martínez Martínez, Cristina

[Sociedad Española de Lenguas Modernas]

Albaladejo Albaladejo, Sara

[ISEN, UMU]

\section{CONSEJO ASESOR}

Adroher Auroux, Andrés María [Arqueología, Universidad de Granada]

Albero Muñoz, $\mathrm{M}^{\mathrm{a}}$ del Mar $\left[\mathrm{H} .^{\mathrm{a}}\right.$ del Arte, Universidad de Murcia]

Alia Miranda, Francisco [Historia Contemporánea, UCLM]

Arciniega García, Luis [Historia del Arte, Universidad de Valencia]
Barrio Barrio, Juan Antonio [Historia Medieval, Universidad de Alicante]

Castellano i Solé, Núria [Egiptología, Schola Didàctica Activa S.L.]

Chapman, Arthur [History Education, University College of London, Reino Unido]

Cid López, Rosa María [Historia Antigua, Universidad de Oviedo]

Cobacho López, Ángel [Derecho, Universidad de Murcia]

Cuenca López, José María [Didáctica de las Ciencias Sociales, Universidad de Huelva]

Egea Bruno, Pedro $\mathrm{M}^{\mathrm{a}}$ [Historia Contemporánea, Universidad de Murcia]

Feijoo Martínez, Santiago [Arqueología, Consorcio Ciudad Monumental de Mérida]

García Atienzar, Gabriel [Prehistoria, Universidad de Alicante]

Ginestí Rosell, Anna [Filología Clásica, Katholische Universität Eichstätt-Ingolstadt]

González Monfort, Neus [Didáctica de las Ciencias Sociales, Universidad Autónoma de Barcelona]

González Soutelo, Silvia [Arqueología, Universidad de Vigo]

Haber Uriarte, María [Prehistoria, Universidad de Murcia]

Hernández de la Fuente, David [Historia Antigua, Universidad Complutense]

Hutson, Scott R. [Anthropology, University of Kentucky, EEUU]

Igual Luis, David [Historia Medieval, UCLM]

Irigoyen López, Antonio [Historia Moderna, Universidad de Murcia]

Jover Maestre, Francisco Javier [Prehistoria, Universidad de Alicante]

Mahony, Simon [Digital Humanities, University College of London, Reino Unido]

Marsilla de Pascual, Francisco Reyes [Técnicas historiográficas, Universidad de Murcia]

Martínez-Burgos García, Palma [H. ${ }^{\text {a }}$ del Arte, UCLM]

Mathis, Christian [Didaktik der Geschichte, PH Zürich]

Miralles Maldonado, José Carlos [Filología Clásica, Universidad de Murcia]

Molina Gómez, José Antonio [Historia Antigua, Universidad de Murcia]

Mónica Ghirardi [Historia Moderna, Universidad Nacional de Córdoba, Argentina]

Navarro Espinach, Germán [Historia Medieval, Universidad de Zaragoza]

Noguera Celdrán, José Miguel [Arqueología, Universidad de Murcia]

Ortiz Heras, Manuel [Historia Contemporánea, UCLM]

Panzram, Sabine [Historia Antigua, Universität Hamburg]

Pérez Molina, Miguel Emilio [Filología Clásica, Universidad de Murcia]

Prados Martínez, Fernando [Arqueología, Universidad de Alicante]

Sánchez Ibáñez, Raquel [Didáctica de las Ciencias Sociales, Universidad de Murcia]

Sancho Gómez, Miguel Pablo [Educación, UCAM]

Victoria Moreno, Diego [Historia Contemporánea, UNED]

Vilar García, María José [Historia Contemporánea, Universidad de Murcia]

Vivas Sainz, Inmaculada [H. ${ }^{\text {a }}$ del Arte, UNED]

Zamora López, José Ángel [Próximo Oriente Antiguo, CCHS-CSIC] 

Artículos

El estilo decorativo en las primeras producciones cerámicas en el valle del río Vinalopó (Alicante).

Silvia Martínez Amorós.

Límites históricos del Ateísmo: increencia en la Grecia Antigua.

Ramón Soneira Martínez. .33

Dynamics of Power: an Architectural Reading of the Concentration of Power (Ullastret, 4th-3rd Century BC).

David Jesús Cebrián Martínez.

La mujer como exemplum. Subversión, desafío y resistencia en Valerio Máximo.

Lidia González Estrada.

The narrative framing of violence in teaching resources about the Spanish Conquest of America.

Ángela Bermúdez Vélez y Diego Argumero Martínez.

Modelos de conciencia histórica en el alumnado de Educación Secundaria: tradición, simbología y contextualización en torno a los restos del franquismo.

Diego Miguel-Revilla y María Sánchez Agustí.

La importancia de la contextualización curricular en la enseñanza de la Historia en México.

Enrique Bautista Rojas.

Experiencia didáctica para la enseñanza de la historia contemporánea a través de las fuentes en Educación Superior.

Nayra Llonch-Molina y Verónica Parisi-Moreno 161

\section{Reseñas}

Prados, F., Jiménez, H., Martínez, J.J. (Eds.) (2017). Menorca entre fenicis i púnics / Menorca entre fenicios y púnicos. Murcia: Centro de Estudios del Próximo Oriente y la Antigüedad Tardía de la Universidad de Murcia. 320 págs.

Pete Missingham

Bravo Bosch, M. J. (2017). Mujeres y símbolos en la Roma Republicana. Análisis jurídico-histórico de Lucrecia y Cornelia. Madrid: Dykinson. 333 págs.

Borja Méndez Santiago.

Karp, M. (2016). This Vast Southern Empire: Slaveholders at the Helm of American Foreign Policy. Cambridge: Harvard University Press. 360 pages.

Kevin Caprice.

Livi-Bacci, Massimo (2012). A Short History of Migration. Cambridge: Polity Press. 157 pages.

Alejandro Salamanca Rodríguez. 189

Normas de publicación/Publishing rules 



\title{
The Narrative Framing of Violence in Teaching Resources about the Spanish Conquest of America ${ }^{1}$
}

\author{
Marcos narrativos de la violencia en recursos educativos \\ sobre la Conquista de América
}

Bermúdez Vélez, Ángela²

Deusto University

Argumero Martínez, Diego ${ }^{3}$

Deusto University

Recibido: 31/01/2018

Aceptado: 20/04/2018

Para citar este artículo: Bermúdez Vélez, A., y Argumero Martínez, Diego (2018). The narrative framing of violence in teaching resources about the Spanish Conquest of America. Panta Rei. Revista Digital de Ciencia y Didáctica de la Historia, 93-118.

ISSNe: $2386-8864$

DOI: $10.6018 /$ pantarei/2018/5

\section{Resumen}

La conquista de América (1492-1550) es un tema profundamente polémico que aún genera controversias por la violencia que conllevó y por la magnitud de sus consecuencias. Este estudio analiza cómo diferentes narrativas sobre la Conquista de América presentes en materiales educativos de historia utilizados en España y en Colombia, representan la violencia intrínseca a este proceso histórico. A través de un análisis narrativo y discursivo se identificaron cuatro narrativas principales: una narrativa de encuentro, una narrativa de modernidad, una narrativa de dominación y una narrativa de devastación. Cada una explica la conquista y enmarca la violencia de manera diferente. Los autores plantean que comprender cómo las narrativas históricas representan la violencia es fundamental para promover la construcción de culturas de paz desde la enseñanza de la historia.

\section{Palabras clave}

Enseñanza de la historia, temas controversiales, textos escolares, análisis del discurso, pensamiento crítico.

\section{Abstract}

The conquest of America (1492-1550) is a deeply contested topic that still generates controversy due to the violence it entailed and the magnitude of its consequences. This study analyzes how different narratives about the Spanish Conquest of America present in history education resources used in Spain and Colombia represent the violence intrinsic to this event. Data was analyzed through narrative and discursive theory. Four main narratives were identified: a Narrative of Encounter, a Narrative of Modernity, a Narrative of Domination, and a Narrative of Devastation.

1 This project was funded by the European Union/Marie Curie Grant (FP7-PEOPLE-CIG) from 2012 to 2016, and the Spencer Foundation Research Grant from 2013 to 2014.

2 Para contactar con la autora: Ángela Bermúdez Vélez. Universidad de Deusto. angeber@deusto.es.

3 Para contactar con el autor: Diego Argumero Martínez. Universidad de Deusto. diego.argumero@deusto. es. 
Each one explains the Conquest and frames the violence in a different way. The authors argue that understanding how historical narratives represent violence is essential to foster peace building through history education.

\section{Keywords}

History instruction, controversial issues, textbooks, discourse analysis, critical thinking.

\section{Introduction}

The Conquest of America (1492-1550) is a deeply contested topic, both in public opinion and in scholarship. 1492 symbolizes the turning point of a worldwide reconfiguration, the legacies of which are still visible and conflictive in our times. The commemoration in 1992 of the 5th centennial of Columbus' landing in the Americas exposed to the world the massive controversy that surrounds this event, perhaps reflective of the violence it entailed, the magnitude of its consequences, and of the unequal distribution of gains and losses. While some celebrated, in a festive mood, the Hispanisation and Christianization of the New World, to others 1992 called for the condemnation of five centuries of exploitation and ethnocide. More than two decades later, the controversy is still alive. For instance, every 12th of October Spain celebrates the Day of Hispanicity. Established by law as a National Holiday of mandatory observation, it is meant to commemorate,

The day in history in which Spain, on the verge of concluding the process of State building based on its cultural and political pluralism and the integration of the Kingdoms of Spain in a single Monarchy, begins a period of cultural and linguistic projection beyond European boundaries. (Ley 18/1987 del 7 de Octubre de 1987. BOE, 8-10-1987, num. 241, p. 30149).

In contrast, during his visit to Bolivia on July 2015, Pope Francis asked for forgiveness for the many grave sins that were committed against the native peoples of America: "in the name of God, I humbly ask for forgiveness, not only for the offenses of the Church herself, but also for crimes committed against the native peoples during the so-called Conquest of America" ("The Pope's speech", 2015).

These statements reveal competing narratives of the Conquest of America that are still 'alive and kicking', and their relevance in contemporary public life shows the extent to which the past is present in our understanding of the current world. How does formal history education fit in this picture? This paper reports on the findings of a study that analyzed the accounts of the Spanish Conquest of America found in a sample of nine history-education resources used in Spanish and Colombian schools. The goal was to determine what narratives of this event appear in history classrooms today and more in particular, how they represent the violence inherent to it. Understanding how violence is represented in historical narratives, and the extent to which it is made an object of critical reflection, is of fundamental importance to shed light on the potential contribution of history education to the formation of critical citizens that are prepared to participate in the building of sustainable cultures of peace.

\section{Theoretical overview and relevant literature}

\subsection{Narrative and narrative framing}

In their seminal work on the cultural mediation of cognitive development, Bruner (1986, 1991) and Vygotsky (1978) explained that individuals structure their sense of self and reality through 'narrative thinking,' using narratives as 'cultural tools' that provide systems of representation and meaning-making particular to their socio-historical contexts. Historical narratives, in particular, establish how we understand the past, our own reality, and our role in it (Andrews, 2007; Carretero \& Bermúdez, 2012; Wertsch 1997, 2002). For instance, narratives compose coherent storylines that, arranging series of events, establish a diachronic sense of time and imply causal explanations. Characters with intentions, beliefs, and values enact the events described; and these descriptions 
highlight the role of individual and collective agency within the complex mechanisms of historical causation. Making connections between past and present, and between the macro level of social processes and the micro level of individual experience, they afford a sense of continuity between accounts of the past, experiences in the present, and imaginations of the future. Further, narratives articulate moral questions that probe the implications of past events for our lives today (Haste \& Bermudez, 2017). Different scholars argue that it is precisely the narrative structure of historical consciousness what allows individuals to see themselves as historical creatures, orient in time, and contextualize their identity (Ricoeur, 1983; Rüsen, 2004; Seixas, 2006). Narrative is therefore a fundamental meaning-making tool. But as a cultural tool, historical narratives are socially situated and interpretative reconstructions of the past, driven by the concerns we have and the questions we ask in the present and by the social functions that, implicitly or explicitly, we attribute to them. This applies to different kinds of narratives. Communities generate social narratives to give meaning to their experiences and to preserve or erase them from collective memory (Andrews, 2014; Bar-Tal, 2000; Ricoeur, 2004). Yet, since narratives embody a vantage point and are politically positioned, minorities, marginalized or alternative groups within or outside a community maintain parallel narratives. A considerable amount of empirical research has been devoted to the analysis of how teachers, students and textbook narratives deal with the differing perspectives of dominant/marginal or majority/minority groups (Anderson, 2012; Anderson \& Metzger, 2011; Barton \& McCully, 2005; Clark, 2007; Epstein, 2009; Shear, Knowles, Soden, \& Castro, 2015). Narratives also result from the strategic production of particular groups or organizations (including the Nation-State), which generate institutional narratives that instrumentalize the past in support of particular agendas. As studies of history curricula shows, official and unofficial versions of the past are constantly defined and redefined, specially following major socio-political changes (Ahonen, 1997; Carretero, 2011; Ferro, 2003; Oglesby, 2007; Tulviste \& Wertsch, 1994). Finally, historiographical traditions also produce different academic narratives. Differences depend largely on the questions asked by historians, their theoretical approaches, and the sources and methods of analysis they use; but they also reflect ideological positions regarding the past and its relation to the present.

The concept of narrative framing denotes the different ways in which narratives provide frames of meaning within which we establish the nature and significance of events of the past, and negotiate our own sense of self and reality. Wertsch (2004) has shown how specific accounts in history textbooks conform to schematic narrative templates or master narratives that organize accounts of the past around key dominant motifs such as progress or freedom. Narrative framing consists of a predefined template that determines what is included and excluded from an account, and how events are interpreted in light of social values and motifs that define a storyline and provide a sense of direction and end-goal of historical processes.

In turn, discourse theorists stress the dynamic nature of narrative framing. They understand narratives as action-oriented productions that serve a chief social function of facilitating the negotiation of personal and collective identities and of the contested meaning of social events and practices (Billig, 1987; Gee, 2011; Haste \& Abrahams, 2008). In this case, narrative framing refers to the active processes that come into play in producing and consuming historical narratives. According to Haste and Bermudez (2017), narratives become lay social theories through which people learn what to take for granted and what to question, what to regard as natural and normal, and what to regard as problematic. Further, narratives include and exclude certain events and actors, and of those included, some are placed in the foreground and others in the background. In this manner, narratives define what happened, who made things happen and on whom, and what aspects should be regarded as more or less important. Historical actors make available certain identity categories that allow readers to position themselves and others, and thereby engage in a dynamic process of identity building (Bermúdez, 2012; Harré \& Moghaddam, 2003). Thus, the representation of historical actors entails normative claims about how one ought to act.

Narrative research and the concept of narrative framing have been instrumental to scholarship on the intersection of history, civic and peace education. Studies in peace education document how narratives of war affect the way that individuals understand particular situations of conflict (Bekerman \& Zembylas, 2012; Salomon, 2004; Raviv, Oppenheimer, \& Bar-Tal, 1999). Bar-Tal (2000) notes that these narratives provide youth with collective memories and a collectively held ethos that explain the nature and history of the conflict, and each side's role in it, justifying one's own position, and 
denigrating the other's. In the field of history education, an increasing number of studies investigate how different societies teach about their violent past. Scholars point to the challenges of teaching about difficult histories, or uncomfortable episodes of collective memory on which there is no single narrative that is accepted by all (Barton \& McCully, 2007; Cole, 2007; Garrett, 2011; Hess, 2010; Savenije, van Boxtel, \& Grever, 2014; Sheppard, Katz, \& Grosland, 2015; Zembylas, 2014). As competing narratives are brought to the classroom, making sense of these uncomfortable episodes of the past requires facing various intellectual, ethical and emotional complexities. School history becomes a prime site of negotiation, particularly as curricula, textbooks, teachers and students evoke different social, institutional, and academic narratives. In this paper we focus on the narratives included in history education resources, and what they make available to the readers.

\subsection{Different narratives on the Spanish Conquest of America}

The Spanish Conquest of America is a prime example of a difficult history on which no agreement upon narrative exists, and the concept of narrative framing is useful to understand why and how competing narratives provide very different accounts about this event. We will highlight five different narratives that are easily identifiable as academic narratives, but intersect with social narratives and, in some cases, generate institutional narratives. These are by no means all the narratives that historiography has produced about the Conquest of America, but they appear to be the ones that have had the strongest impact in the production of teaching resources in the two countries included in this study. These narratives will be used as a framework for the analysis of how the Conquest of America is represented in history education resources.

Traditional historiography represented the Conquest as the Discovery of a New World and the subsequent process of civilizing the Indians and setting the basis of the culture we cherish today. Stern (1992) notes that at the time of the quincentennial, this narrative appeared as a neoconservative form of 'hispanophilia' that purported that Spain opened to Native Americans the path of progress towards a better future. We will call this a 'narrative of civilization' in which the Conquest is understood as a historical achievement of Spain and as a process of cultural transmission of a language, a value system and a religion towards the American continent (Aram, 2008). Sánchez, Arias and Egea (2016) characterize this narrative as the traditional model of teaching the Discovery in Spain, which reflects a national-catholic ideology, in which historical milestones are led by successful (heroic) historical characters, and in which the native people of America are represented in a generic, and sometimes pejorative way, without geographical or cultural references.

Different historians have questioned the naive and misleading effects of the concept of discovery, not only from an indigenous perspective that asserts the existence of millenary cultures independently of European awareness (Horna, 2013; León-Portilla, 1966; Mann, 2005) but also from a European viewpoint. Already in 1958 O'Gorman argued convincingly that in the eyes of the early conquerors, America was more the product of invention that of discovery. Also challenging the celebratory rendition, most contemporary historiography recognizes the violence and devastating consequences of the Conquest. The annihilation of an indigenous population of about seventy million in the short span of fifty years lead Todorov $(1982,1984)$ to consider this "the greatest genocide in the history of humanity" (1984, p. 138). Bartolomé de Las Casas provided an early depiction of its cruelty; and since then, numerous scholars have evidenced the many abuses and injustices, and the desolation it brought about (Dri, 1991; Dussel, 1983, 1991; Halperín Donghi, 1992; Horna, 2013; Mann, 2005; Todorov, 1984).

Besides this shared recognition, historians offer disparate explanations of this event (Dussel, 1991; Dieterich Steffan, 1991). Different historiographical perspectives represent it as a) the original step towards the creation of a new capitalist world order, b) an invasion and genocide, c) a complex process of encounter between two cultural worlds, or d) the embryonic expansion of European modernity. Building upon their distinct dominant motifs we will refer to four other narratives: a Narrative of Domination, a Narrative of Devastation, a Narrative of Encounter, and a Narrative of Modernity. 
The Narrative of Domination draws from Marxist and neo-Marxist historiography and structuralist theory, as well as from the philosophy and theology of liberation (Dri, 1991; Dussel, 1983, 1991; Stern, 1992). The rise in the 1960' and 70's of leftist political thinking, booming Latin American revolutionary movements, and the II Vatican Council, generated a new frame for a) questioning the Eurocentric discourse that propounded the progress brought by the Conquest, b) focusing the analysis on the power relationships that led to pillage and exploitation, and c) exposing the tight structural relationship between processes of evangelization and domination. Marxist historiography advocated for going beyond a positivist analysis that reduced history to the actions and experiences of individual empirical subjects. This made possible an explanation of the process of domination based on revealing the underlying dynamics and relationships that while not evident to the consciousness of historical actors, determined their actions and beliefs (Sánchez Ferlosio, 1991).

In turn, the Narrative of Devastation draws from different strands of Latin American and cultural studies, as well as from the reflection of Indigenous movements. As Dieterich Steffan (1991) points out, Latin America witnesses throughout the 80's the onset of neo-liberal reforms at the same time that the dominant paradigms of capitalism and socialism showed serious challenges. Faced with this landscape after a long history of colonialism, many turned their eyes back toward the indigenous past, to find in it a sense of identity and self-worth (Sánchez Ferlosio, 1991; Horna, 2013). In the years prior and following 1992, indigenous movements and various sympathetic intellectuals raised their voice to condemn the massive celebrations of the 5th Centennial challenging also the conventional discourse that underscored the ideas of hybrid cultural heritage and mestizaje (Dussel, 1991; Stern, 1992; Todorov, 1982, 1984). These accounts privileged the voice and experience of Indigenous cultures previously excluded from historical accounts.

The Narrative of Encounter draws upon a tradition of social and cultural history influenced by the Annals School that investigated economic processes, social life and mentalities, giving lesser attention to political themes. The Annals' influence is also visible in its hostility to the class analysis of Marxist historiography. With an anthropological inclination, this tradition focused historical inquiry about the Conquest of America on the reconstruction of social worldviews and practices, their expressions in micro-histories of daily life that shaped relations between actors, and their transformation in longterm processes. Páramo (1992) argues that many of the most painful episodes of the conquest and colonization resulted from the misunderstanding between Europeans and Native Americans around issues on which they were extraordinarily different (e.g. the value of gold and the economy, religion and morals). However, he says, "they were also surprisingly similar in other aspects, and it is notable that despite the distance and novelty there was also communication and coherence" (p. 127). These scholars also draw from theories on the ethics of communication advanced by the Frankfurt School and developed in Latin American philosophy and theology of liberation. From this perspective, Dussel $(1983,1991)$ developed a critical account of the Conquest as a cultural encounter between others, that is, a cultural encounter marked by dialogic boundaries and inequality. Todorov (1984) also raised the question of the construction of otherness in this encounter, and the tragic moral consequences it brought about.

The Narrative of Modernity draws from a tradition of Colonial historiography that investigated the origins and dynamics of the Colonial state, economy and society in America (Stern, 1992). Seen as the preamble of colonial times, the Conquest is the time of transfer of Spanish political, social and economic institutions, and the beginning of their adaptation as they interplay with the institutions, social practices and mentality of indigenous societies (Lynch, 1992; Sempat Assadourian, 1992). Arguing with Marxist historiography, this tradition stressed that analytic categories and explanations should emerge from the empirical analysis of data about events in their context, rather than from imposed theoretical models that led to sweeping generalizations (Colmenares, 1990). This influence is visible in the emphasis that the Narrative of Modernization puts on explaining the complex interplay between spheres of society, rather than asserting the pre-eminence of economic structures that predefine power relations. It also manifests in the effort to explain Spanish actors and their experience in context, in ways that, as Stern (1992) argued, frees them from "the kingdom of immeasurable 
historical demons" and restores them to more recognizable human dimensions - "exploiters, powerseekers, visionaries and partner beneficiaries whose projects of social dominance were crammed with struggles, initiatives and responses from within and from outside" (pp. 37-38).

\subsection{Political violence}

This study aimed to identify what narratives of the Spanish Conquest of America appear in history education resources today, and more specifically, how different narratives represent the violence inherent to this historical process. For this reason, it is important to clarify the concept of violence used in the analysis. Of the different manifestations of violence we focus on political violence (rather than e.g. gender violence, interpersonal violence), which is understood as the reliance on organized violence as a means of settling disputes and attaining allegedly higher political, social or economic goals (Barash \& Webel, 2002). Galtung (1996) identifies three types of violence: direct, structural and cultural, in order to show that violence is not reduced to its visible and material manifestations (direct). Direct violence stems and is fed by other less visible forms of violence, which take place through social structures of exclusion and oppression (structural violence), and cultural practices that normalize and justify violence (cultural violence). The interplay between these different types of violence is useful to understand the different manifestations of violence during the Conquest of America.

Further, this conceptualization of political violence highlights its instrumental nature as a purposeful strategy in which the "other" is treated as a disposable means to achieve disputed goods. Said in other terms, violence is a purposeful strategy to obtain desired goals through the domination or annihilation of others who are rendered as obstacles to ones self-satisfaction, or as beings of lesser value that deserve a violent treatment. Different scholars argue that this instrumental nature renders violence as a profoundly immoral approach to conflict (Arendt, 1970; Bernstein, 2015; Galtung, 1996; Todorov, 1984). Therefore, a critical understanding of violence involves more than the depiction of direct physical violence. It requires a clear exposition and discussion of the different forms of violence, their interaction, and the magnitude of its dramatic consequences.

\subsection{Textbook narratives of the Spanish Conquest of America}

Empirical research on this matter has clustered in two topics. A first topic has focused on whether students of Spanish and Latin American countries are taught the same or different stories, and the extent to which textbooks in each context reproduce an official account (Carretero, Jacott, \& López-Manjón, 2002; Carretero \& Kriger, 2011). For instance, in their study of Mexican and Spanish textbooks published before 1994, Carretero et al. (2002) found that both countries deployed a master narrative directed towards the building of a national identity. However, Spanish textbooks narrated the discovery of America, and described the heroic enterprise of a handful of Spaniards who, facing many obstacles, carried out the enormous task of exploring and colonizing the continent, bringing cultural advancement and laying the foundations of what is now Hispanic-America. In contrast, Mexican textbooks told the story of two cultures of equal status that met, mixed and transformed. This account stressed both the harmful impact for Indigenous people and the birth of a new mestizo culture.

A second topic focuses on how representations of the Conquest have changed over time, reflecting both social transformations and the influence of new historiographical traditions. Up until the mid-1980s the dominant account in history textbooks in most Latin American countries portrayed the Conquest as a process of civilization (Braslavsky, 1991; Colmenares, 1991). This account omitted or misrepresented the experiences and perspectives of Indigenous cultures, depicted western-Christian culture as superior, and concealed long-term economic and political processes. Likewise, Spanish textbooks glossed over socioeconomic practices such as slavery or 
the subjugation of indigenous people (Carretero, et al., 2002; Carretero \& Kriger, 2011). However, different studies show a progressive abandonment of the account of civilization (Colmenares, 1991; Valls, 2013; Von Borries, 1991; Sánchez, Arias, \& Egea, 2016). Throughout the 1980's, textbooks started to incorporate other accounts that described the diversity of native cultures, introduced new language and contents that challenged the traditional depiction of Indigenous people as 'savages', and touched on issues such as the demographic catastrophe, economic exploitation, or cultural exchange between European and Indigenous cultures.

These previous studies provide important points of reference for our research. We maintain the comparative approach between Spanish and Latin American contexts, but for the latter we focus on Colombia, a country that had not been considered in previous studies. We also analyzed teaching resources produced in a wide span of years (1970-2011). Even though our interest was not to examine how narratives change over time, this ensured that our sample included enough variety of narratives and their corresponding representations of violence. Compared to previous studies, our interest went beyond identifying the official narratives that dominate history textbooks. Given the diversity of academic and social narratives on the topic, we were curious to see if and how they had translated into the accounts of the Conquest of America provided by different history education resources. In addition, we wanted to take the analysis a step further, focusing on how the different narratives represent the violence of the Conquest. This important issue has not been analyzed explicitly or systematically.

\subsection{The Conquest of America in the history curricula of both countries}

The topic of the Conquest of America appears in similar places in Colombian and Spanish curricula. In the first case, the topic is studied in the second year of Basic Secondary Education ${ }^{4}$ (called 7th grade), as part of the subject of Social Sciences. In Spain, the Conquest is typically studied in second year of Compulsory Secondary Education (ESO) as part of the subject of Geography and History ${ }^{5}$. Table 1 presents basic information about the place that the topic occupies in both curricula, as well as the related evaluable learning standards.

It is difficult to assert how much time is spent on the Conquest of America during school hours in both countries. However, an analysis of the curriculum and of the table of contents of textbooks gives us a general idea on this matter. In the case of Colombia, a whole thematic unit is dedicated to the Conquest and Colony in America, starting with the indigenous societies prior to the Conquest, up to the colonial institutions. This unit covers the factors that allowed the arrival of Europeans to America, the Conquest of America, and the consequences of this process.

In contrast, in the Spanish curriculum the Conquest of America is a topic of secondary importance. The curriculum for the first three years covers from Prehistory until the end of 17th century. Within that, one content block is devoted to the Modern Age, which includes three topics: a) Renaissance and Humanism, b) Geographical discoveries, and c) Modern monarchies. Within the topic of Geographical discoveries students learn about Castile and Portugal and Conquest and colonization of America.

4 This corresponds to the second cycle in the formal education system in Colombia; it is composed of four grades, each one year long, named from sixth to ninth, usually starting at the ages of 11 or 12 years (Ministerio de Educación Nacional, https://www.mineducacion.gov.co/1759/w3-article-233839.html).

5 The Educación Secundaria Obligatoria (Compulsory Secondary Education) is an obligatory educational cycle that completes basic education. It consists of four academic courses that are usually held between 12 and 16 years of age (Ministry of Education Culture and Sport, https://www.mecd.gob.es/educacion-mecd/areaseducacion/estudiantes/educacion-secondary.html). The curriculum defines that the topic of the Conquest must be taught within the first three years of ESO. 
Table 1

The Conquest of America in the curriculum

\begin{tabular}{|c|c|c|}
\hline & Colombia & Spain \\
\hline School grade & $\begin{array}{l}\text { 2nd year of Secondary Basic } \\
\text { Education }\end{array}$ & $\begin{array}{l}\text { 2nd year of Compulsory } \\
\text { Secondary Education }\end{array}$ \\
\hline Subject & $\begin{array}{c}\text { Social Sciences } \\
\text { (include History, Geography } \\
\text { and Democracy) }\end{array}$ & Geography and History \\
\hline Subject approximate weekly & $3-4$ & $3-4$ \\
\hline hourly intensity & $\begin{array}{l}\text { (one of the nine compulsory } \\
\text { subjects. All together must } \\
\text { occupy at least } 80 \% \text { of the } \\
\text { class schedule) }\end{array}$ & $\begin{array}{c}\text { (one of five structural subjects } \\
\text { in the ESO's curricula. This } \\
\text { subject must occupy at } \\
\text { least } 50 \% \text { of the total class } \\
\text { schedule) }\end{array}$ \\
\hline Subject sub-section & Geography and history & History \\
\hline $\begin{array}{l}\text { Topic importance based on } \\
\text { hierarchy in curricula }\end{array}$ & $\begin{array}{l}\text { Block 6: Conquest and Colony } \\
\text { in America } \\
>\text { Conquest of America }\end{array}$ & $\begin{array}{c}\text { Block 3: History } \\
\text { >Modern Age } \\
>\text { Geographical discoveries } \\
\text { >Conquest of America }\end{array}$ \\
\hline $\begin{array}{l}\text { Assessable learning standards } \\
\text { related to the Conquest of } \\
\text { America }\end{array}$ & $\begin{array}{l}\text { Identify the economic, social, } \\
\text { political and geographical } \\
\text { factors that led to the Conquest } \\
\text { of America. } \\
\text { Analyze the consequences } \\
\text { of the Conquest and the } \\
\text { Colony, from a social, political, } \\
\text { economic and cultural } \\
\text { perspective. }\end{array}$ & $\begin{array}{l}\text { Explain the different causes } \\
\text { that led to the discovery of } \\
\text { America for Europeans, to their } \\
\text { conquest and colonization. } \\
\text { Weigh conflicting } \\
\text { interpretations about the } \\
\text { conquest and colonization of } \\
\text { America. }\end{array}$ \\
\hline
\end{tabular}

Source: Own elaboration based on the Royal Decree 1105/2014 for Spain, Law 115 of 1994 and Basic Standards of Competencies in Social Sciences (2004) for Colombia.

\section{Methodology}

This qualitative study investigated two research questions: a) What narratives of the Spanish Conquest of America appear in history education resources used in Spanish and Colombian schools? (b) How do the different narratives of the Conquest of America that appear in different educational resources represent the violence inherent to this historical process? The decision to focus the analysis on these two countries stems from the larger research project of which this study is part. Understanding Political Violence Through History Education was a qualitative international research project on history education and its potential contribution to the construction of cultures of peace. The research was conducted in Spain, Colombia and the United States. Three historical events were selected in each country to focus data collection and analysis. The Conquest of America 
was a shared event selected for the cases of Colombia and Spain 6 .

Data for this study was collected during 2013-2014. The sample included nine history-education resources published between 1970 and 2013 that are still used to some degree in Colombian or Spanish schools. The time-span of the sample was purposefully designed to capture a diversity of narratives of the Conquest of America offered by different historiographical traditions. In order to identify possible teaching resources, we consulted with educators who had taught the topic and with textbook authors, booksellers, and other researchers on the topic. Based on their nominations, we selected nine resources using the following process and criteria.

We first selected two history textbooks for each country, which were recently produced by large publishing companies. The purpose of this criterion was to include textbooks that followed the official curricular guidelines and were widely sold and used.

We then included one additional history textbook per country, but the rationale here was that they represented some kind of innovative effort (when first produced), either in its content or in its pedagogic approach. These textbooks were not necessarily produced by large publishing companies nor recently published. Their innovative feature referred to the time when they were first produced.

Finally, we added three other educational resources that were not designed or used as conventional textbooks, but were nominated by teachers and booksellers as important additional teaching resources, despite their years of publication. They were written or produced by scholars or research centers, and they did not follow any official curricular guidelines. The main criterion here was that they offered different perspectives on the topic, for instance, informed by different historiographical approaches. Only Colombian resources were included following this criterion because no such resources were nominated by teachers, authors or booksellers in Spain. It is worth noting that the only resource nominated (SP-KAIROS-2003), corresponded to criterion 2 (innovative textbooks). Interestingly, one of the Colombian resources, the book "Un Mundo Jamás Imaginado (A World Never Imagined), 1492-1992"7, includes several chapters written by Spanish historians, but it is not used in Spanish Schools. Table 2 specifies the sampling criteria and the resources selected to match them.

From each of the nine resources in the sample we selected the narratives contained in the chapters or sections dedicated to the Conquest of America (1500-1550), and when applicable, specifically focused on the Conquest of the Nueva Granada, which included what is currently Colombia.

Data analysis was conducted in two phases. The first phase addressed the first research question: What narratives of the Spanish Conquest of America appear in history education resources used in Spanish and Colombian schools? This analysis employed both an emic and an etic or theory-driven coding strategy (Saldana, 2012). Data were first coded inductively to identify salient or recurrent themes in the representation of historical events and actors. These themes were then clustered in categories that corresponded to the different academic/social traditions identified in the theoretical framework. Table 3 synthesizes the final categorization of themes into four narratives of the Conquest identified in the resources analyzed. Three researchers coded the data separately, and met to discuss and arrive at mutually agreeable themes, coding, and categorizations.

Once the coding was concluded, all the excerpts from different teaching resources that were coded under the same category (narrative) were pulled together in a N-vivo report. Four reports were used to craft four narrative profiles (Maxwell, 2013; Miles \& Huberman, 1994) that synthesized how each narrative explained the Conquest of America.

6 For further details, visit: http://undervio.deusto.es.

7 From which we extracted one chapter on the Conquest of Nueva Granada coded as (CO-MELO-1992).

Panta Rei (2018), 93 - 118 
Table 2

Criteria for textbook sampling ${ }^{8}$

Criteria 1: History textbooks recently produced by large publishing companies

Santillana (2013) Sociales 7. Los Caminos del Saber. (CO-SANTI-2013)

Norma (2011) Sociales para Pensar 7. (CO-NORMA-2011)

Santillana (2012) Geografía e Historia 2 ESO. Proyecto Los Caminos del Saber. Vol. 2. (SPSANTI-2012)

Ibaizabal (2009) Ciencias Sociales, Geografía E Historia 2 ESO. Proyecto i.By2 (SP-IBAIZ-2009)

Criteria 2: Innovative history textbooks

Norma (1987) Historia de Colombia: Introducción a la Historia Social y Económica. (CONORMA-1987)

Octaedro (2003) Ciencias Sociales, Geografía E Historia, 2 ESO Proyecto Kairós. (SPKAIROS-2003)

Criteria 3: Other resources used by teachers

Galeano E. (1971) Las Venas Abiertas de América Latina (CO-GALEA-1971)

Vega, R. (1988) 12 de Octubre de 1492. ¿Descubrimiento o Invasión? (CO-VEGA-1988)

Melo, J. (1992) La Conquista de la Nueva Granada 1- Las Primeras Expediciones a la Costa Atlántica. (CO-MELO-1992)

Source: Own elaboration. ${ }^{9}$

The second phase of analysis addressed the second research question: How do the different narratives represent the violence inherent to this historical process? This analysis employed a discursive approach to operationalize the concept of 'narrative frame' in a set of analytic questions to examine different aspects that shape the representation of violence (see Table 4). Data compiled in the narrative profiles (developed during phase 1) were examined against these questions by three separate researchers who then met to compare and discuss their responses and arrive at mutually agreeable interpretations.

8 For ease of readability, we use codes to refer to the resources. Codes indicate the country of use, the publisher or author, and the year of publication. See the References section for bibliographic details.

9 Notes about these textbooks:

CO-NORMA-1987 was among the first to introduce a critical historiography focused on social and economic processes. Booksellers note that it is a popular item in the market of used books, and several Colombian teachers confirmed that they use it as a supplementary material to plan their lessons or provide additional reading material.

SP-KAIROS-2003 was part of an alternative history education project (KAIROS) that aimed to engage students in active historical inquiry and develop their capacity for historical understanding. It is still used as supplementary material, particularly by teachers interested in constructivist teaching and learning.

CO-GALEA-1971 is an iconic account of Latin American history written for a lay audience by an acclaimed intellectual of the Latin American left. It continues to be a best-seller and many Colombian history teachers still use it as a prime companion resource.

CO-VEGA-1988 was written by a respected Marxist historian to communicate to a lay audience the history of the Conquest told from the perspective of the vanquished. It is marginally used today, but several Colombian teachers remarked on how it made a difference in their teaching of this topic.

CO-MELO-1992 is a chapter in a book "Un Mundo Jamás Imaginado 1992 (A World Never Imagined), 14921992" written for young people by leading international historians at the time of the $V$ Centenary of 1492. We selected the chapter focused on the Conquest of the Nueva Granada, which included what is currently Colombia. This book has been reprinted several times, and is still quite popular. Booksellers noted that new editions sell fast. 
Table 3

Salient themes and narratives

\begin{tabular}{ll}
\hline \multicolumn{1}{c}{ Narrative of Encounter } & \multicolumn{1}{c}{ Narrative of Modernity } \\
\hline Cultural diversity & Social, economic, political and cultural \\
Two-way exchange & transformations (Europe) \\
Mutual transformations & New needs and possibilities (Europe) \\
Multicultural legacy & Exploration and new settlements (America) \\
& Emergence of colonial institutions \\
\hline \multicolumn{1}{c}{ Narrative of Domination } & \multicolumn{1}{c}{ Narrative of Devastation } \\
\hline Transformation of power relations (Europe) & Wealth of Indigenous ancient cultures \\
Exploitation and domination & Invasion and extermination \\
Accumulation of wealth & Indigenous resistance \\
New world order & Material and cultural loss \\
\hline
\end{tabular}

Source: Own elaboration.

Table 4

Analytic questions for a discursive analysis of representations of violence

\begin{tabular}{|c|c|}
\hline Analytic question & Shed light on how narratives... \\
\hline What events are included and excluded? & Define 'what happened.' \\
\hline $\begin{array}{l}\text { What events (of those included) are placed in } \\
\text { the foreground and background? }\end{array}$ & Establish what is more or less important. \\
\hline $\begin{array}{l}\text { What historical actors are included and excluded, } \\
\text { and which are given more or less voice? }\end{array}$ & Emphasize or marginalize perspectives \\
\hline $\begin{array}{l}\text { What events, actors and practices are labeled or } \\
\text { characterized as violent? }\end{array}$ & $\begin{array}{l}\text { Position different actors, and define how the } \\
\text { reader should regard them. }\end{array}$ \\
\hline $\begin{array}{l}\text { What actions and practices are attributed to } \\
\text { the different historical actors? What qualities, } \\
\text { motives, and needs are attributed to explain } \\
\text { them? }\end{array}$ & $\begin{array}{l}\text { Grant or remove agency and responsibility for } \\
\text { violence. }\end{array}$ \\
\hline $\begin{array}{l}\text { How are events located in or dislocated from } \\
\text { long-term processes and larger scenarios? }\end{array}$ & $\begin{array}{l}\text { Define the scope and significance of particular } \\
\text { events. Imply necessity, purpose and } \\
\text { consequences of violence. }\end{array}$ \\
\hline $\begin{array}{l}\text { What stances does the text adopt regarding the } \\
\text { use of violence? }\end{array}$ & $\begin{array}{l}\text { Define what violent practices are taken-for- } \\
\text { granted, normalized, justified, questioned or } \\
\text { challenged. }\end{array}$ \\
\hline
\end{tabular}

Source: Own elaboration. 


\subsection{Comparative approach}

As explained earlier, the goal of this study was to determine how violence is represented in different historical narratives of the Conquest of America, and the extent to which violence is made an object of critical reflection. While the main purpose was not to compare national textbook narratives per-se, the inclusion of Colombian and Spanish textbooks was expected to provide the sample of data with a greater diversity of narratives ${ }^{10}$. Given the visible disparity of viewpoints expressed in the public realm in Spain and in Latin American countries regarding the Conquest and the moral import of its violence, it was assumed that such difference would also be manifested in history textbooks. This assumption was also in line with the findings of previous research (Carretero et al., 2002; Carretero \& Kriger, 2011).The first phase of analysis, focused on establishing the different narratives of the Conquest that appear in teaching resources, maintained a comparative approach leading to identify which narratives where more or less prominent in the different resources of both countries. Yet, once the four narratives were identified, the comparison between Colombian and Spanish textbooks was put aside. The second phase of analysis focused on reconstructing how each narrative framed the representation of violence. This shift in analytic focus was also supported by the fact that, as it will be explained in the following section, there was not a notable difference in the narratives that appeared in the history textbooks of the two countries.

\section{Findings}

The first phase of the analysis identified four narratives about the Conquest of America present in the history education resources analyzed: A Narrative of Encounter, a Narrative of Modernity, a Narrative of Domination, and a Narrative of Devastation. No significant elements of a Narrative of Civilization were found in this sample.

The detailed analysis of the content of each narrative evidenced that they tell in fact very different stories about the Conquest of America, depending on how they define starting and ending points, include and exclude facts and actors, and situate different aspects in the foreground and background of the account. What is most relevant in these findings is that the representation of violence depends on the narrative frame. Different narratives recognize different types of violence, they position victims and perpetrators in particular ways that attribute agency and responsibility, and they give more or less attention to the gains, costs and consequences of violence. Table 5 synthesizes and contrasts the four representation of the Conquest and the narrative framing of violence in each one.

10 For a similar reason, the sample included teaching resources used today but produced over a wide span of years, even though our study did not intend to analyse how narratives have changed over time. 
Table 5.

Framing of violence compared

\begin{tabular}{|c|c|}
\hline Narrative of Encounter & Narrative of Modernity \\
\hline $\begin{array}{l}\text { Mistreatment and cultural imposition. } \\
\text { Tone: Regretful /conciliatory. } \\
\text { Violence was circumstantial > The 'encounter' } \\
\text { was unequal and not always harmonious. } \\
\text { Unclear agency and responsibility. } \\
\text { Little is said about the "othering" of Indigenous } \\
\text { people in the 'encounter'. } \\
\text { Acknowledges violent episodes BUT the } \\
\text { magnitude and depth of this violence is } \\
\text { watered-down. } \\
\text { Foreground > Cultural diversity, equal worth, } \\
\text { and two-way exchange and transformations. } \\
\text { Background > Inequality, cruelty and } \\
\text { destructiveness of the 'encounter'. }\end{array}$ & $\begin{array}{l}\text { Killings, massacres, pillage, abuse, slavery } \\
\text { (Physical, social and economic violence). } \\
\text { Tone: Disapproval. } \\
\text { Violence was circumstantial > Conquering troops } \\
\text { used violence and left damage behind } \\
\text { Spanish agency \& responsibility. } \\
\text { Indigenous fight back in self-defence. } \\
\text { Little elaboration on Indigenous experience of } \\
\text { violence. } \\
\text { Acknowledges physical, social and economic } \\
\text { violence BUT systematic nature, and dramatic } \\
\text { consequences are not represented. } \\
\text { Foreground > Emergence of European } \\
\text { Modernity, new needs and possibilities, Spanish } \\
\text { expansion, new colonial institutions. } \\
\text { Background > Indigenous experience, systemic } \\
\text { nature of violence and dramatic consequences } \\
\text { of the Conquest. }\end{array}$ \\
\hline
\end{tabular}

\begin{tabular}{ll}
\hline \multicolumn{1}{c}{ Narrative of Domination } & \multicolumn{1}{c}{ Narrative of Devastation } \\
\hline $\begin{array}{l}\text { Plunder, domination and exploitation } \\
\text { (Physical, cultural and structural violence). }\end{array}$ & $\begin{array}{l}\text { Plunder, annihilation and cultural devastation } \\
\text { (Physical, cultural and structural violence). }\end{array}$ \\
Tone: Denounce / blame. & Tone: Outrage. \\
Violence was instrumental (means to an end) & Violence was the essence of Spanish occupation \\
$>$ It facilitated the accumulation of wealth. & and genocide. \\
Agency is diffused but Spain and Europe & Spanish agency \& responsibility / Indigenous \\
benefit from violence. & agency and legitimacy of violent resistance. \\
Little elaboration on Indigenous experience of & Describes the experience of violence (suffering \\
violence. & and loss) from an Indigenous perspective. \\
Exposes underlying dynamics that sustain & Connects physical social, economic and cultural \\
violence BUT agency is diffused and violence & violence. \\
appears as an inevitable force. & BUT violence is questioned depending on the \\
Foregrounds > Accumulation of wealth. & actors and context. \\
Primacy of economic interests, socio-political & Foregrounds > Indigenous cultural wealth and \\
systems that sustain them. & resistance, material and cultural loss. \\
Background > Individual agency, context & Background > Perspective and experience of \\
and choices. Differences among actors and & Spanish actors, complex confrontations and \\
complex alliances and confrontations. & alliances that existed among Spanish actors and \\
& between Spanish and Indigenous people. \\
\hline Source: Own elabong
\end{tabular}

Source: Own elaboration. 
In the pages that follow we flesh out these findings in detail. We reconstruct how each narrative represents the Conquest of America, and discuss how each narrative frames violence.

Besides the narrative framing of violence, a striking finding was that few history education resources were dominated by one single master narrative. Rather, most of them integrated themes from different narratives into what seem coherent accounts of the Conquest. Calculating the percentage of text coded as corresponding to each narrative, we estimated the distribution and preponderance of these narratives in the teaching resources examined (See Figure 1).

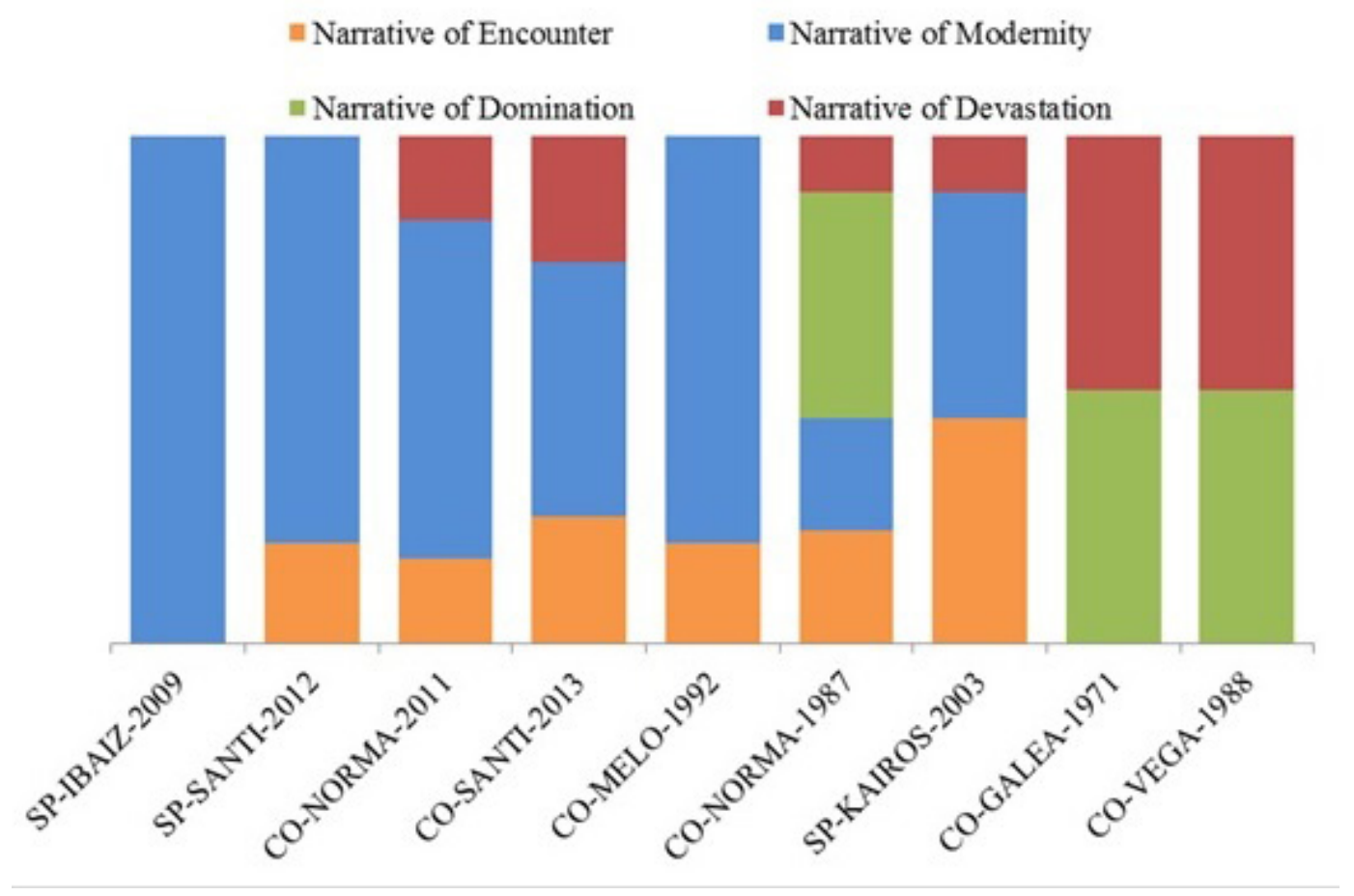

Figure 1. Distribution of narratives in resources examined Source: Own elaboration.

The Narrative of Modernity is clearly preponderant across textbooks, both in Colombia and in Spain, while it is virtually absent in the other resources (non-textbooks) published in 1971 and 1988. The Narrative of Encounter appears in all but one of the recent and older textbooks, but rather marginally. The Narrative of Domination does not appear in recently published textbooks, neither in Colombia nor in Spain, while its presence is noteworthy in the resources published in 1971 and 1988, as well as in the 1987 textbook. Finally, the Narrative of Devastation appears prominently in the 1971 and 1988 resources, and marginally in the recent $(2011,2013)$ and older (1987) Colombian textbooks, and in the Spanish innovative textbook (2003). This narrative is absent from the two recently published Spanish textbooks $(2009,2011)$ and also from one of the Colombian resources that is not a textbook.

A third interesting finding was that there is no radical discrepancy between Spanish and Colombian textbooks, as we had expected. Textbooks in both countries privilege the Narratives of Modernity and Encounter, and there are no signs in either country of a narrative of Civilization. However, it is also visible that current Spanish textbooks do not include elements of a Narrative of Devastation that portrays the destruction and genocide, which appears, even if marginally, in Colombian textbooks and in the Spanish alternative resource. 


\subsection{Narratives of the Conquest}

\section{a. Narrative of Cultural Encounter}

The Narrative of Encounter represents the Spanish Conquest of America as a process of communication and exchange between cultures that understood themselves in very different terms, but engaged with each other through various symbolic and material processes. The narrative foregrounds the cultural differences between Indigenous and European societies, but also their equal worth. These themes mark the beginning of a narrative plot that highlights the diversity and wealth of millenary Indigenous cultures that existed prior to Spanish arrival. For instance, SP-KAIROS-2003 point out the technological advances achieved in the field of agriculture by the Mexicas: "In order to gain terrain for cultivation from the Lake, they developed a technique that allowed them, through rafts made with canes and cloth, to hold peat above the water" (p. 126), and then claimed that none of the coetaneous European countries had managed to take advantage of swamps with such efficacy.

The account describes the encounter between these Indigenous societies and Spaniards. After Columbus' first meeting with the Taino people in 1492, the narrative focuses on the on-going exchange of goods and customs between America and Europe. CO-MELO-1992 describes the socio-cultural exchanges that took place in the context of the encomienda, a system of dependent labor and tribute that granted Spanish conquerors control over groups of Indigenous population.

[The encomienda] served the purpose of safeguarding the conquistadors' lives and making indigenous people learn the Spanish culture: the language, religion, some European crops and customs. Spaniards, in turn, also learned various indigenous customs, especially regarding food. The mestizos, children of Spanish men and Indigenous women, inherited the customs of both groups (p. 168).

The emphasis on two-way exchanges counters the idea of a unidirectional (civilizing) transformation. Instead, this narrative tells how the different cultures affected each other and gave birth to hybrid cultural legacies. According to CO-SANTI-2013, the Conquest entailed a re-invention of the world, because it affected everything, both in the new continent and in Western countries. For example, "Europeans proved that the Earth was round and had four continents (...), they were driven to re-think their geography, history and religion" (p. 206). In turn, "Indigenous people underwent an even more drastic change; not only did they had to change their territories, but they were also forced to take on the European religion, languages, cultures and even illnesses. On the other hand, new generations resulted from cultural union and mix, giving rise to new ways of viewing the world and the rights of cultures" (p. 207).

The narrative calls the reader's attention to what remains of that exchange in America today, focusing particularly on socio-cultural legacies such as the "predominance of European languages (Spanish, English, Portuguese) in America and the miscegenation, resulting from the inter-breeding of the conquistadors and the conquered America" (CO-SANTI-2013, p. 200).

Aside of unavoidable references to individuals like Columbus, most of the characters are collective actors, which, even if briefly, are located in the sociocultural contexts that informed their beliefs and practices. Hence, SP-KAIROS-2003 explains that "The Aztecs possessed the land without private property (...) they were self-sufficient, with predominant relations of reciprocity and mutual aid" (p. 134); while CO-NORMA-1987 explains that, "From the 8th to the 15th centuries (...) the Peninsular Spanish, whose religion was Christian, struggled to expel the Arabs. The continuous struggle made the Peninsular an adventurous, belligerent and deeply mystical man" (p. 62).

Further, the narrative acknowledges that the 'encounter' was unequal and not always harmonious. In fact, some resources alternate terms between 'encounter,' 'shock,' and 'clash'. In line with this, they also refer violent actions that describe the Conquerors' mistreatment of Indigenous population and the imposition of their culture. For instance, CO-SANTI-2013 stated that Indigenous people "were forced to adopt" the European culture (p. 207). However, despite these 
acknowledgments, the magnitude and depth of violence that characterized the Conquest is watereddown. Consider the following excerpt,

The evangelization of Indians was one of the conquistador's objectives. The Church founded schools in which indigenous cultures were studied in order to evangelize them effectively. But they also repressed indigenous religious practices considered to be mistakes that needed correction. The Christianization of Indians profoundly transformed their culture, to the point that the Christian element is currently definitive in their cultural manifestations (SP-KAIROS-2003, p. 145).

This excerpt asserts that evangelization was accompanied with repression. Yet, through language choices it lessens the violence. The destruction of complex cultural systems is referred to, softly, as a 'profound transformation'; and in saying that the Church evangelized Indians effectively "but also" repressed their religious practices, the two processes are somewhat dissociated, casting a shadow over the intrinsic relationship between evangelization and forced acculturation. Similarly, SP-SANTI-2012 refers to the asymmetric plunder of resources by simply stating that 'in exchange' of European foods and goods precious metals and agrarian products were "exported" (p. 186); and CO-SANTI-2013 says that Indigenous people "had to change their territories" (p. 207) rather than give them up. Silences are as telling as explicit language use. Little is said about the deeply rooted dynamic of "othering" of Indigenous people that tainted the encounter, or about the tragic legacies it left behind. Likewise, the depiction of 'mestizaje' as the result of the "inter-breeding" of European and Indigenous people obscures the asymmetry of these relationships that often amounted to violent rape.

All in all, this narrative does not include or invite an explicit reflection about the origins, dynamics and consequences of the violence inherent to the Conquest. Placing the themes of cultural diversity, two-way exchanges, and mutual transformation in the foreground of the account, the inequality, cruelty and destructiveness of the 'encounter' is displaced to the background. In this manner, this narrative seems to articulate a conciliatory discourse directed towards appeasing conflicting interests and experiences: Yes, the Conquest involved violence, but it brought two worlds together and laid the foundations of the diverse cultures we cherish today.

However, understanding how was the encounter between such different cultures does not need to imply concealing its violence. However, if the narrative constructed in education resources foregrounds the themes of cultural diversity and exchange at the expense of relegating the themes of inequality and otherness, the idea of a 'cultural encounter' becomes an euphemism that obscures violence. A similar pattern is found in textbooks in the United States, where historical narratives driven by the theme of multiculturalism increase the presence of minorities in different historical processes but tend to downplay conflict and inequality to promote consensus narratives of social cohesion, racial reconciliation, democratic progress and national development (Anderson \& Metzger, 2011; Anderson, 2012). May and Sleeter (2010) argue that in conventional multiculturalism "the focus is on getting along better, primarily via a greater recognition of, and respect for, ethnic, cultural, and/or linguistic differences", but this curricular focus "abdicates any corresponding recognition of unequal, and often untidy, power relations that underpin inequality and limit cultural interaction" ( $p$. 4).

\section{b. Narrative of the Expansion of European Modernity}

The Narrative of Modernity represents the Conquest of America as the early process of Spanish-European expansion in the New World, marking the beginning of the modern world, and in particular, the prelude of colonial times in America. The plot starts in Europe, highlighting a host of social, political, economic and cultural transformations that set the stage for Columbus' expeditions. As CO-SANTI-2013 explains, various factors motivated Spanish expansion across the Atlantic: 
Blockade of trade routes through the Mediterranean (...); increase in merchants' and bankers' economic capacity and interest in funding expensive voyages (...); commercial interests, which fostered technical advancements in navigation, astronomy, [and] cartography; political and religious unification of the Spanish territory (...); definitive expulsion of Moors from the Iberian Peninsula (p. 204).

These descriptions emphasize the sense of newness that surrounded the incipient formation of the modern absolutist state in Spain and the mercantilist economy in Europe. These transformations opened new needs (trade routes, sources of gold, markets, religious mission) and new possibilities (private resources, economic capacity, scientific and technical tools) generating an expansive momentum that led the Spanish to the New World.

Following the description of Columbus' first voyage and landing, this narrative focuses on the subsequent inland explorations, and the transformation of private adventures into formal conquering enterprises that connected individual conquerors with the Spanish Crown. CO-SANTI-2013 explains that "the first expeditions to American lands were an adventure for the Spanish troops; firstly, on the coasts and thence, toward the interior; these adventures gradually turned into Conquest processes, when the European explorers began to dominate nuclei of indigenous population" (pp. 208-209). These accounts describe the micro-dynamics of the expeditions that founded cities and took gradual control over land and population. Over time -the narrative goes on- new relationships and institutions developed in the New World, extending and adapting elements of the Castilian modern state, because America was perceived as a prolongation of Spain (SP-SANTI-2012). For example, SP-IBAIZ-2009 point out that the American territories "were organized politically and administratively through new structures and that the most significant was the so-called 'Encomienda', which took place in the agricultural domain" (pp. 243-246). The account thus ends in America under Spanish rule, as these newly implanted institutions give way to the Colonial era.

In this account of exploration and settlement, the Conquest is the work of cartographers, sailors, soldiers and priests; ordinary people lured by the fantasy of a new world, the prospect of gaining wealth and status, or a missionary spirit. Yet, individual actors embody social groups (e.g. bankers and merchants) and institutions (e.g. Governors, Monarchy), within which exist different perspectives and interests. The characters portray a Spanish society in tension and transformation, for example regarding the hierarchy and conflicts among conquistadores, or the conflictive relationships between the Crown and the encomenderos.

Compared to European actors, Indigenous actors take a secondary role. They appear in the narrative as conquerors advance in their journeys; and whether they embrace them amicably or defend themselves, most of their actions are responses to what Spaniards do. Yet, in describing their relationships, the conquerors are often positioned as perpetrators of violence, and indigenous violence is regarded as self-defense. This is mostly visible in Colombian resources: "The Spaniards' habit of capturing and enslaving Indians, aggravated by the violence some exerted in trying to force the Indians to give them gold (...) moved the natives to begin using weapons to receive the Spaniards: above all, bows and poisoned arrows" (CO-MELO-1992, p. 161). With Rodrigo Alvarez Palomino in charge of the new settlement, the city had temporary prosperity, based on the pillage of Indigenous populations. Pedro Vadillo was named Governor of Santa Marta, but the looting and the abuse continued (CO-NORMA-1987, p. 71).

As these excerpts evidence, this narrative depicts different forms of physical and social violence (killings, pillage, slavery, etc.) conveying a clear tone of disapproval. It also explicitly attributes agency and responsibility to Spaniards. Nevertheless, these descriptions of violence seem to fall short if we consider the scale, systematic nature, and dramatic consequences that are not represented here. Three discursive features help to explain this:

a) The Narrative of Modernity is constructed primarily through the eyes of the Conquerors, so while violent episodes are mentioned, there is little elaboration on the experience lived by Indigenous communities or on the effects this violence bore upon their ways of life. 
b) The narrative plot, structured around the process of exploration and settlement, portrays violence as an effect of the Conquest -the damage left behind as the conqueror troops advanced rather than as an intrinsic quality of it.

c) The emphasis put on the ambition of Conquerors, an uncontrollable thirst for gold and power that was exacerbated as expeditions advanced, highlights the personal and circumstantial manifestations of violence while it obscures the systemic nature of the conquerors' violence, the institutional basis that made it possible, the social discourses that justified it, and the profound consequences it had in an array of social relations that derived from it and remain to our days.

\section{c. Narrative of Domination}

The Narrative of Domination represents the Conquest as a cog in the gear system that mobilized the original accumulation of wealth that made possible the development of European capitalism. This narrative emphasizes the primacy of economic interests and the socio-political systems that sustain them. The plot begins by explaining the social transformations that redefined power relations in Europe. CO-NORMA-1987 argues that the Discovery of America was a consequence of the expansion of commercial capitalism; also explains that "the expansion of commerce stimulated the development of a monetary economy in Europe. However, currency was scarce and it was necessary to find new productive sources of gold and silver" (pp. 60-64). Also describes some stages of this process, like how the bourgeoisie was formed and the dynamics of the original accumulation of capital. Likewise, CO-VEGA-1988 point out how the unification of Spain allowed the monarchy to "subordinate the nobility and aristocracy, to create a national army and to expel the last Moorish bastion from Spanish soil" (p. 36).

These transformations propelled Europe to a position of global supremacy inaugurated with the Conquest of America. The plot moves quickly through voyages and first encounters to focus on the transformation of the initial plunder into systemic relations of domination and exploitation that defined colonialism. In CO-GALEA-1971 students read,

Metals grabbed from the new colonial dominions not only stimulated European economic development, one may even say that they made it possible. The looting of accumulated treasures was followed by systematic exploitation in mine pits and tunnels, through the forced labor of Indians and black slaves who had been abducted in Africa (...) All along the process, from the extraction of metals to the supply of foodstuffs, each region (...) produced what was expected from it by Europe: Each product, stowed in the hold of galleons that ploughed the ocean, became a purpose and a fate (p. 44).

The narrative concludes announcing the creation of a new world order that reconfigured relations in every order, in and between America, Spain and Europe.

The discovery and conquest of America marks the dawn of Capitalism in Europe

(...) Nevertheless, for Spain things were different, for industrial and productive sectors do not consolidate there; rather, parasitic gentlemen and the landowner nobility were strengthened. They lived comfortably off America's gold and silver, as well as off the Spanish people's misery (CO-VEGA-1988, p. 40).

Very few individual actors feature in this narrative. For the most part, the Conquest is a story of collective actors -aristocrats, bourgeois, peasants, artisans, merchants, priests, Indians and black slaves- which are characterized by the function they serve in the machinery of Capitalism (producing, buying, selling, accumulating wealth, evangelizing, or working in mines and pits). Framed like this, plunder and exploitation were not so much a matter of the excessive behavior of ambitious men, but rather part of the cycles of capital investment, circulation and accumulation: Emerging Capitalism generates the 'development of a monetary economy' that requires 'productive sources of gold and silver', as well as raw materials, labor force and markets. While this narrative exposes the underlying 
structures and dynamics that drove historical actors, these are for the most part stripped off agency, merely enacting the dictates of a system. Indians too have little agency, as they are positioned as objects of the action of others who subdue, enslave and abduct them.

The language used provides a charged portrayal of violence. The Conquest is a process of plunder and exploitation. Europe snatched America's treasures, and condemned Indigenous peoples and black slaves to forced labor in mines and pits. More than cases of individual, sporadic or circumstantial mistreatment, this narrative highlights the systemic and relentless violence that was necessary to dominate indigenous peoples. Violence is explained as an intrinsic structural quality of the Conquest that served the function of facilitating the accumulation of wealth. This instrumental nature of violence is further stressed by calling attention to the tight relationship between evangelization and domination. The Church is positioned as another piece of the machinery, in which different gears operate in concert. The Church provided the worldview that legitimated the domination and violence; CO-GALEA-1971 claims that "The sword and the cross marched together in the Conquest and plunder of Latin America" (p. 30); and point out the relevance of the ideological justifications:

The bleeding of the New World became an act of charity, an argument of faith. (...)

The viceroy of Mexico considered there was no better remedy than work in the mines for curing the Indians' 'natural evil'. Juan Ginés de Sepúlveda, a renowned Spanish theologian (...), argued that Indians deserved the treatment they received because their sins and idolatries constituted an offence to God (p. 63).

\section{d. Narrative of Devastation}

The Narrative of Devastation represents the Conquest of America as a Spanish occupation that, despite Indigenous resistance, annihilated the vast majority of the population and destroyed millenary cultures. The account begins in America, with detailed descriptions that emphasize the diverse yet advanced development of indigenous societies. CO-GALEA-1971 for instance, highlights their skills in engineering and architecture, as well as the "astonishing precision in which Mayans measured time and space, and how they discovered the value of the figure zero before any other people in history" (p. 66).

Contrasting with this beginning, the rest of the narrative represents a traumatic process of invasion, genocide, destruction and loss. Different resources cite the Mayan manuscripts of the 16th Century, the Books of Chillam Balam, to convey the sorrow of Indigenous peoples facing the arrival of Spaniards': "Foreigners with rubicund beards have come, the Sun's sons, fair-colored men. Ay! Let us be sad because they have arrived! (...) the messengers of divinity's signal, (...) the great amassers of rocks (...) those who explode fire through the end of their arm" (SP-KAIROS-2003, p. 131). "Ahau... ay! Let us be sad because they have come, ay! From Itza, your Gods will be worthless! This true God that comes from the sky will only speak of sins, he will only teach about sins" (CO-VEGA-1988, p. 55).

The narrative then focuses on the abuses that characterized the relationships between Conquerors and Indigenous people. Excerpts from de Las Casas' Very Brief History of the Destruction of the Indies are cited to portray their cruelty and contempt: "Because these peoples are so happy and rich, so humble and patient, so easily subjected, they have been regarded as little more than beasts" (CO-VEGA-1988, p. 46). In face of Spanish occupation and abuse, Indigenous communities display diverse forms of organized resistance. The plot moves back and forth from episodes of victimization to episodes of defiance, insurrection and survival, whether they were successful or not. CO-VEGA-1988 describes the indigenous resistance as heroic considering their technology disadvantage against Europeans and also references the episode of collective suicide made by the Tainos before falling in the invaders' hands. Despite their resistance, the Conquest brought destruction and loss, and the narrative highlights the scale of the disaster faced by indigenous peoples. 
Indigenous groups had complex ways of relating amongst themselves, which included conflicts but also forms of solidarity and exchange that were lost after the Spaniards' arrival (...) The indigenous economy and social systems were disjointed and their religious traditions were harshly attacked by Catholicism (...) Many native languages disappeared, while the European languages were imposed (CO-SANTI-2013, p. 213).

The narrative concludes in Latin America today, noting the traumatic legacy of the Conquest: "In just a few years, the Europeans destroyed cultures (...) and upon their ruins, they shaped a different type of society: unequal and unfair, where racism, discrimination and the exploitation of Indians, blacks and mestizos predominate" (CO-VEGA-1988, p. 26). In this narrative of devastation, Spaniards are positioned as outsiders, invaders, and generators of suffering and loss. Their actions are predominantly violent -they kill, loot, rape women, burn homes and destroy temples- and their character voracious, cruel, untrustworthy and arrogant. In stark contrast, Indigenous actors embody ancient wisdom. Their wealth of experience and knowledge showed in sophisticated technologies (e.g., they measured time and space with astounding precision), as well as in efficient agricultural systems, balanced ecological relations, and various forms of communal social organization. A tendency to portray actors in black and white, homogeneously and unambiguously good or bad, omit the complex confrontations and alliances that existed among Spanish actors and between Spanish and Indigenous people.

Indigenous people are also positioned as victims of Conquerors' violence, but the narrative grants them full agency and capacity for organized resistance. Independently of their success, they come across as bearers of strong determination, self-respect and endurance. In this account, Indigenous communities were forced to employ violence after they were deceived and betrayed, and considering the military superiority of Spaniards, violent resistance is presented as a courageous and righteous response.

Distinctively, CO-VEGA-1988 uses the proper names of many indigenous leaders. This is noteworthy as none of the other narratives name indigenous actors other than the great leaders like Atahualpa or Cuactemoc. While they refer to various Spaniards with their proper names, they speak generically of 'indigenous peoples' or at the most they use tribal names -Tainos, Incas, Chibchas. In sum, this narrative represents the magnitude and depth of violence that characterized the Conquest of America, as well as the complex interactions between its physical, economic, and cultural manifestations.

The scale of the destruction is heightened by the narrative plot that begins with the cultural wealth that existed prior to Spanish arrival; and the recurrent themes of suffering and loss that represent the experience of violence from the victims' perspective.

\section{Conclusion}

A first striking finding of this study was the absence in current resources of the Narrative of Civilization that dominated Colombian and Spanish textbooks in the past. While this is consistent with what other studies have found (Colmenares, 1991; Valls, 2013; Von Borries, 1991; Sánchez, Arias, \& Egea, 2016) it was surprising considering the presence it still has in other spheres of public life in Spain. Adding to the annual celebration of Día de la Hispanidad, the president of Radio y Televisión Española (RTVE, national public television network) claimed in a recent speech that:

The Discovery of America has been the most important event in the History of Humanity, after the birth of Christ. Spain was never a colonizer, it was an evangelizer and a civilizer [and] feeling regret for the disappearance of the Aztec empire is more or less like feeling regret for the defeat of the Nazis in World War II, [because] the Aztec culture was a bloody totalitarianism founded on human sacrifices ("El presidente de RTVE", 2017). 
Perhaps this disparity between political and school discourse indicates the weight of academic narratives on history teaching, which appears to have been more receptive to newer historiographic interpretations.

This study provides a more discriminating picture of the different accounts that replaced the narrative of civilization, both in Spain and in Colombia. Existing research (Colmenares, 1991; Valls, 2013) notes that the progressive abandonment of the narrative of civilization opened the space for an account that recognizes cultural diversity, different forms of socio-economic domination, or the impact that America had in Europe. Yet, the findings of our study highlight important differences within what has been described as one general transformation. The four narratives identified provide very different explanations of Conquest, and what is more important, they frame violence in quite different terms. The rejection of the narrative of civilization that omitted all episodes of violence or blatantly justified it does not necessarily mean that the narratives that replaced it offer a thoroughly critical representation of it.

The most significant contribution of this study is showing that the four narratives of the Conquest provide distinct frameworks that define what is said and not said about the violence inherent to this historical event: the positioning of victims and perpetrators, the establishment of agency and responsibility, the types of violence recognized, and the attention given to gains, costs and consequences.

As explained in the analysis section, the Narrative of Domination, the Narrative of Devastation, the Narrative of Encounter and the Narrative of Modernity all acknowledge that the Conquest of America entailed some degree of violence, and refer to physical, socio-economic and cultural manifestations that show that violence entailed much more that killing. Furthermore, all four position Indigenous people as victims and attribute responsibility to Spaniards. Also common is a critical tone regarding the use of violence, even though this ranges from softer regret to strong indignation. However, besides these positive similarities, each narrative represents the violence of the Conquest in different ways that have advantages and shortfalls for advancing a critical understanding of violence.

The Narrative of Encounter and the Narrative of Modernity represent violence as circumstantial, sporadic and interpersonal occurrences, casting a shadow over its instrumental, pervasive, and systemic nature. These two narratives do not include or invite an explicit reflection about the origins, dynamics and consequences of the violence of the Conquest. All this is located as an ancillary feature in the background of a story that is really about something else - the foundation of current multicultural societies or the expansion of modernity and the prelude to colonial America. Considering that a combination of these two narratives is what predominates in current history textbooks, this shortfall is worrisome for approaches to history education that seek to contribute to peace-building and the development of a critical citizenry.

These shortfalls are better addressed in the Narratives of Domination and Devastation. The former reveals the complex interaction between the social structures that sustained violence -the economic furnace that fed it, the sociopolitical institutions that made it possible, and the social and religious discourses that justified it. This narrative represents violence as an instrument, a means to an end, thus disclosing who gained from it and at whose expense. In turn, the Narrative of Devastation is the only one that represents the traumatic experience of violence, highlighting its profound, longlasting and devastating impact on Indigenous communities, their life styles, livelihood, and identities. The recurrent themes of suffering and loss reveal the dark sides of the cultural legacies and the modern institutions that America inherited from this violent past. However, these two narratives fall short on other fronts. The Narrative of Domination is so focused on reconstructing the structural dynamics that generate violence independently of individuals' awareness and volition that concrete historical actors fade away. The more abstract social entities that feature in this account tend to be stripped of agency and choice, obscuring the many instances in which concrete actors were faced with choices, doubts, dilemmas and controversies, but still opted for the expedience of violent means. This, coupled with the systemic scope, may end up normalizing violence as an inescapable 
force of history and human affairs. Not unrelated to this is a challenge evidenced in the Narrative of Devastation. In the face of the pervasive, relentless and systemic violence faced by Indigenous communities, was it feasible to resist without responding with violence? If not, did this make it legitimate and righteous? These questions are not explicitly discussed, and as a result, the critique of violence made in this narrative is dependent on who enacts it and who is on the receiving end. These shortfalls are further reinforced by a tendency to portray historical actors in black and white, homogeneously and unambiguously good or bad.

In sum, any one of the four narratives is not comprehensive enough to provide an integral critical representation of the violence of the Conquest. The explicit and reflective articulation of different narratives may be beneficial as each one sheds light on what the others obscure. This has an important pedagogical implication that echoes literature on teaching difficult histories that often recommends pedagogies based on multi-perspectivity (McCully, 2018; Shaheed, 2013). Engaging students in analyzing different narratives can teach them that historical accounts are interpretative reconstructions of past, based on evidence but driven by the questions we ask in the present. Thus, teaching with multiple narratives allows for a valuable cross-examination that may yield a more sophisticated understanding of the claims and silences of the different accounts. Adopting such approach, history education will be better positioned to make violence visible and to foster a critical reflection about its causes, consequences, social implications, and alternatives. This is a distinct contribution that history education can make to the construction of sustainable cultures of peace.

\section{References}

Ahonen, S. (1997). A transformation of history: The official representations of history in East Germany and Estonia, 1986-1991. Culture \& Psychology, 3(1), 41-62.

Anderson, C. B. (2012). Misplaced multiculturalism: Representations of American Indians in U.S. history academic content standards. Curriculum Inquiry, 42(4), 497-509. Retrieved from https://onlinelibrary.wiley.com/doi/abs/10.1111/j.1467-873X.2012.00604.x

Anderson, C. B., \& Metzger, S. A. (2011). Slavery, the civil war era, and AfricanAmerican representation in U.S. history: An analysis of four states' academic standards. Theory and Research in Social Education, 39(3), 393-415.

Andrews, M. (2007) Shaping history: Narratives of political change. Cambridge: Cambridge University Press.

Andrews, M. (2014). Narrative imagination and everyday life. Oxford: Oxford University Press.

Aram, B. (2008). Leyenda negra y leyenda doradas en la conquista de américa: Pedrarias y Balboa. Madrid: Marcial Pons.

Arendt, H. (1970). On violence. New York: Harcourt, Brace \& World, Inc.

Barash, D., \& Webel, C. (2002). Peace and conflict studies. Thousand Oaks, CA: Sage.

Bar-Tal, D. (2000). Shared Beliefs in a Society: Social Psychological Analysis. Thousands Oaks, CA: Sage Publications.

Barton, K. C., \& McCully, A. W. (2005). History, identity, and the school curriculum in Northern Ireland: An empirical study of secondary students' ideas and perspectives. Journal of Curriculum Studies, 37(1), 85-116.

Barton, K. C., \& McCully, A. W. (2007). Teaching controversial issues... Where controversial issues really matter. Teaching History, 127, 13-19.

Bekerman, Z., \& Zembylas, M. (2012). Teaching Contested Narratives: Identity, Memory and Reconciliation in Peace Education and Beyond. Cambridge: Cambridge University Press.

Bermúdez, A. (2012). The Discursive Negotiation of Cultural Narratives and Social Identities in Learning History. In M. Carretero, M. Asensio, \& M. Rodríguez-Moneo (Eds.), History Teaching and National Identities. International Review of History Education, Vol. 5. Charlotte, CT: Information Age Publishing.

Bernstein, R. J. (2015). Violencia: pensar sin barandillas. Barcelona: Editorial Gedisa. 
Billig, M. (1987). Arguing and Thinking: A Rhetorical Approach to Social Psychology. Cambridge: University Press.

BOE (2015). Boletín Oficial del Estado (España), n. 3. 3-01-2015.

BOE (1987). Boletín Oficial del Estado (España), n. ${ }^{\circ}$ 241. 8-12-1987.

Braslavsky, C. (1991). Los libros de texto en su contexto: Argentina 1975-1989. In M. Riekenberg (Ed.), Latinoamérica: Enseñanza de la historia, libros de texto y conciencia histórica (pp. 6076). Buenos Aires/Madrid: FLACSO/Georg Eckert Institut.

Bruner, J. (1986). Actual minds, possible worlds. Cambridge, MA: Harvard University Press.

Bruner, J. (1991). The Narrative Construction of Reality. Critical Inquiry, 18(1), 1-21.

Carretero, M. (2011). Constructing Patriotism: Teaching History and Memories in Global Worlds. Charlotte, NC: IAP.

Carretero, M., \& Bermúdez, A. (2012). Constructing Histories. In J. Valsiner (Ed.), Handbook of Sociocultural Research (pp. 625-646). Oxford: Oxford University Press.

Carretero, M., \& Kriger, M. (2011). Historical Representations and Conflicts about Indigenous People as National Identities. Culture \& Psychology, 17(2), 177-195.

Carretero, M., Jacott, L., \& López-Manjón, A. (2002). Learning History through Textbooks: Are Mexican and Spanish Students Taught the Same Story? Learning and Instruction, 12(6), 651665.

Clark, A. (2007). Representations of Aboriginal People in English Canadian History Textbooks: Toward Reconciliation. In E. Cole (Ed.), Teaching the Violent Past (pp. 123-153). Lanham, MD: Rowman \& Littlefield Publishers.

Cole, E. (ed). (2007). Teaching the Violent Past: History Education and Reconciliation. Lanham, MD: Rowman \& Littlefield Publishers.

Colmenares, G. (1990). Historia Económica y Órdenes de Magnitud. Capítulo 1: La Formación De La Economía Colonial (1500-1740). Manuscript.

Colmenares, G. (1991). La Batalla de los Manuales en Colombia. In M. Riekenberg (Ed.), Latinoamérica: Enseñanza e la historia, libros de texto y conciencia histórica (pp. 122-134). Buenos Aires/Madrid: FLACSO/Georg Eckert Institut.

Dieterich Steffan, H. D. (Ed.). (1991) 1492-1992 La interminable Conquista. Emancipación e identidad de América Latina. Bogotá: Editorial El Búho.

Dri, R. (1991). Teología de la Dominación y la Conquista. In H. Dieterich Steffan (Ed.), 1492-1992 La interminable Conquista (99-128). Bogotá: Editorial El Buho.

Dussel, E. (1983). Historia General de la Iglesia en América Latina. Salamanca: Ediciones Sígueme.

Dussel, E. (1991). 1492: Diversas posiciones ideológicas. In H. Dieterich Steffan (Ed.), 1492-1992 La interminable Conquista (pp. 77-97). Bogotá: Editorial El Buho.

El presidente de RTVE sobre la conquista de América: "España no fue colonizadora, sino evangelizadora" (2017, Abril 4). Eldiario.es. Retrieved from: https://www.eldiario.es/rastreador/ RTVE-Espana-America-colonizadora-evangelizadora 6 629647047.html

Epstein, T. (2009). Interpreting National History: Race, Identity, and Pedagogy in Classrooms and Communities. New York: Routledge.

Ferro, M. (2003). The use and Abuse of History: Or how the Past is Taught to Children. London: Routledge (1st Ed. 1984).

Galtung, J. (1996). Peace by peaceful means. London, New Delhi, Thousand Oaks: Sage.

Garrett, H. J. (2011). The routing and re-routing of difficult knowledge: Social studies teachers encounter when the levees broke. Theory and Research in Social Education, 39(3), 320-347.

Gee, J. P. (2011). An Introduction to Discourse Analysis 4th Edition: Theory and Method. New York: Routledge.

Halperín Donghi, T. (1992). Backward Looks and Forward Glimpses from a Quincentennial Vantage Point. Journal of Latin American Studies, 24(S1), 219-234.

Harré, R., \& Moghaddam, F. M. (2003). The self and others: Positioning individuals and groups in personal, political, and cultural contexts. Westport, CT: Praeger. 
Haste, H., \& Abrahams, S. (2008). Morality, culture and the dialogic self: Taking cultural pluralism seriously. Journal of Moral Education, 37(3), 357-374.

Haste, H., \& Bermúdez, A. (2017). The Power of Story: Narrative, History and Civic Identity. In M. Carretero, S. Berger, \& M. Grever (Eds.), International Handbook of Research in Historical Culture and Education. London: Palgrave MacMillan.

Hess, D. (2010). Controversy in the classroom; the democratic power of discussion. New York: Routledge.

Horna, H. (2013). Hacia una visión indianista de la conquista. Pacarina del Sur, 4(14). Retrieved from: http://www.pacarinadelsur.com/home/indoamerica/616-hacia-una-vision-indianista-dela-conquista?

León-Portilla, M. (1966). ¿Qué es el indigenismo interamericano? América Indígena, XXVI (4), 341359.

Ley 18/1987 del 7 de Octubre de 1987. BOE, 8-10-1987, n. ${ }^{\circ} 241$, p. 30149

Ley 115 del 8 de Febrero de 1994, Por la cual se expide la ley general de educación.

Lynch, J. (1992). The Institutional Framework of Colonial Spanish America. Journal of Latin American Studies, 24(S1), 69-81.

Mann, C. C. (2005). 1491: New Revelations of the Americas Before Columbus. New York: Alfred A. Knopf.

Maxwell, J. (2013). Qualitative Research Design: An Interactive Approach. 3rd Ed. Vol. 41 Okland, CA: Sage.

May, S., \& Sleeter, C. E. (Eds.) (2010). Critical multiculturalism: Theory and praxis. New York: Routledge.

McCully, A. (2018). Teaching history and educating for citizenship: Allies or "uneasy bedfellows" in a post conflict context? In T. Epstein, \& C. Peck (Eds.), Teaching and learning difficult histories in international contexts. A critical sociocultural approach (pp. 160-174). New York: Routledge.

Miles, M. B., \& Huberman, A. M. (1994). Qualitative data analysis: An expanded sourcebook. Newbury Park, CA: Sage.

Ministerio de Educación Nacional (2004). Estándares básicos de competencias en ciencias sociales. Formar en ciencias: jel desafío! Lo que necesitamos saber y saber hacer. Colombia: MEN.

O'Gorman, E. (1958). La invención de América. Mexico: Fondo de Cultura Económica.

Oglesby, E. (2007). Historical Memory and the Limits of Peace Education: Examining Guatemala's Memory of Silence and the Politics of Curriculum Design. In E. Cole (Ed.), Teaching the Violent Past: History Education and Reconciliation. Lanham, MD: Rowman \& Littlefield Publishers.

Páramo, G. (1992). El encuentro. In L. B. Peña \& R. Jaramillo (Eds.), Un mundo jamás imaginado 1492-1992 (pp. 159-171). Bogotá: Santillana.

Raviv, A., Oppenheimer, L., \& Bar-Tal, D. (1999). How Children Understand War and Peace: A Call for International Peace Education. San Francisco: Jossey-Bass Publications.

Ricoeur, P. (1983). Time and Narrative. Chicago: University of Chicago Press.

Ricoeur, P. (2004). Memory, History, Forgetting. Chicago: University of Chicago Press..

Rüsen, J. (2004). Historical Consciousness: narrative structure, moral function, and

ontogenetic development. In P. Seixas (Ed.) Theorizing historical consciousness (pp. 63-85). Toronto: University of Toronto Press.

Saldana, J. (2012). The Coding Manual for Qualitative Researchers. Los Angeles, CA: SAGE.

Salomon, G. (2004). A Narrative-based View of Coexistence Education. Journal of Social Issues, 60(2), 273-287.

Sánchez Ferlosio, R. (1991). Esas Yndias equivocadas y malditas. In Chomsky, et al. El nuevo orden mundial o la conquista interminable (pp. 111-138). Navarra: Txalparta.

Sánchez, R., Arias, L., \& Egea, A. (2016). The perduration of master narratives: The discovery, conquest and colonization of America in the Spanish history textbooks. International Journal of Historical Learning, Teaching and Research, 13(2), 127-137.

Savenije, G., Van Boxtel, C., \& Grever, M. (2014). Learning About Sensitive History: "Heritage" of 
Slavery as a Resource. Theory \& Research in Social Education, 42(4), 516-547.

Seixas, P. (Ed.) (2006). Theorizing historical consciousness. Toronto: University of Toronto Press.

Sempat Assadourian, C. (1992). The Colonial Economy: The Transfer of the European System of

Production to New Spain and Peru. Journal of Latin American Studies, 24(S1), 55-68.

Shaheed, F. (2013). Cultural rights - writing and teaching history. Report of the Special Rapporteur in the Field of Cultural Rights. United Nations. Human Rights Council.

Shear, S. B., Knowles, R. T., Soden, J. G., \& Castro, A. J. (2015). Manifesting Destiny: Re/ presentations of Indigenous peoples in K-12 U.S. history standards. Theory and Research in Social Education, 43(1), 68-101.

Sheppard, M., Katz, D. \& Grosland, T. (2015). Conceptualizing emotions in social studies education. Theory \& Research in Social Education, 43(2), 147-178.

Stern, S. (1992). Paradigms of Conquest: History, Historiography and Politics-The Quandary of 1492. Journal of Latin American Studies, 24(S1), 1-34.

The Pope's speech at the meeting with popular movements in Bolivia. (2015, July 9). Aciprensa. Retrieved from https://www.aciprensa.com/noticias/texto-discurso-del-papa-el-encuentro-conlos-movimientos-populares-en-bolivia-80606.

Todorov, T. (1982). La conquete de l'amerique, la question de l'autre. Paris: Editions du Seuil.

Todorov, T. (1984). The Morality of Conquest. Diógenes, 32(125), 89-102.

Tulviste, P., \& Wertsch, J. V. (1994). Official and unofficial histories: The case of Estonia. Journal of Narrative and Life History, 4(4), 311-329.

Valls, R. (2013). Iberoamérica en la Enseñanza Española de la Historia. Práxis Educativa (Brasil), 8(2), 351-374.

Von Borries, B. (1991). Entre La Pretensión Histórico-Universalista y la Práctica Etnocentrista. Latinoamérica en los Textos De Historia De La República Federal De Alemania. In M. Riekenberg (Ed.), Latinoamérica: Enseñanza De La Historia, Libros De Texto y Conciencia Histórica (pp. 194-211). Buenos Aires/Madrid: FLACSO/Georg Eckert Institut.

Vygotsky, L. S. (1978). Mind in society: The development of higher psychological processes. Cambridge: Harvard University Press.

Wertsch, J. V. (1997). Narrative tools of history and identity. Culture \& Psychology, 3(1), 5-20.

Wertsch, J. V. (2002). Voices of Collective Remembering. Cambridge: Cambridge University Press.

Wertsch, J. V. (2004). Specific narratives and schematic narrative templates. In P. Seixas (Ed.). Theorizing historical consciousness (pp. 49-62). Toronto, ON: University of Toronto Press.

Zembylas, M. (2014). Theorizing "Difficult Knowledge" in the Aftermath of the "Affective Turn": Implications for Curriculum and Pedagogy in Handling Traumatic Representations. Curriculum Inquiry, 44(3), 390-412.

\section{History Education Resources}

(CO-MELO-1992) Melo, J. O. (1992). La Conquista de la Nueva Granada 1- Las Primeras Expediciones a la Costa Atlántica. In L. B. Peña, \& R. Jaramillo (Eds.). Un Mundo Jamás Imaginado 1492-1992 (pp. 159-171). Bogotá: Santillana.

(CO-NORMA-1987) Norma (1987). Historia de Colombia: Introducción a la Historia Social y Económica. Bogotá: Norma.

(CO-NORMA-2011) Norma (2011). Sociales para Pensar 7. Bogotá: Norma.

(CO-SANTI-2013) Santillana (2013). Los Caminos del Saber. Sociales 7. Ciencias Sociales. Bogotá: Santillana.

(CO-VEGA-1988) Vega, R., Castro, L. M., Nájera, I. \& Rodríguez, C. I. (1988). 12 De Octubre de 1492. ¿Descubrimiento o Invasión? Bogotá: Campaña de Autodescubrimiento de Nuestra América.

(CO-GALEA-1971) Galeano, E. (1971). Las Venas Abiertas de América Latina. México: Siglo XXI. . (SP-IBAIZ-2009) Ibaizabal (2009). Ciencias Sociales, Geografía E Historia 2 ESO. Proyecto i.By2. 
España: Ibaizabal.

(SP-KAIROS-2003) Octaedro (2003). Ciencias Sociales, Geografía E Historia, 2 ESO. Proyecto Kairós. España: Octaedro.

(SP-SANTI-2012) Santillana. (2012). Geografía E Historia 2 ESO. Proyecto Los Caminos del Saber. Vol 2. España: Santillana. 


\section{Panta Rei}

PANTA REI es una revista digital de investigación orientada a la Historia y otras ciencias afines. Su principal objetivo es la transmisión del conocimiento científico, dando una oportunidad también a los jóvenes investigadores que quieren abrirse camino en el estudio de las ciencias humanas y sociales. Se compone de estudios originales relacionados con la disciplina histórica así como su didáctica y difusión. Las diferentes secciones que componen la revista son: artículos de investigación, entrevistas a profesionales, recensiones de monografías de actualidad y crónicas de congresos o eventos científicos relevantes.

Todos los artículos publicados son objeto de un proceso de revisión a cargo de un mínimo de dos evaluadores, que se consideran expertos en el ámbito temático del artículo propuesto. Nuestro deseo es poder ofrecer unos contenidos rigurosos, de calidad y de interés.

EI CEPOAT (Centro de Estudios del Próximo Oriente y la Antigüedad Tardía de la Universidad de Murcia) es la institución encargada de la coordinación y gestión de la revista, desde donde anualmente se lanzará la convocatoria para aquellos que estén interesados en publicar sus trabajos, siempre relacionados con la Historia, Arqueología, Historia del Arte, Didáctica de las Ciencias Sociales, etc.

PANTA REI is a digital journal focused on History and other sciences related to it. Its main objective is the transmission of scientific knowledge by giving also an opportunity to young researchers who want to make their way in the study of human and social sciences. It is composed by original studies related to History, as well as its didactics and promotion. The different sections of this journal are: research articles, interviews to professionals, recensions on monographs about current issues and reports about congresses or relevant scientific events.

All the articles published are subject to a revision process carried out by a minimum of two reviewers who are considered to be experts in the field of the article proposed. Our wish is to offer rigorous contents with quality and being of interest to the reader.

CEPOAT (Centre of Studies of the Middle East and Late Antiquity of the University of Murcia) is the institution in charge of the coordination and management of this journal. This is the centre from where the call for papers will be launched for all the people interested in publishing their papers, always related to History, Archeology, Art History, Didactics of the Social Sciences, etc. 


\section{Normas de Publicación}

El autor se compromete a enviar trabajos originales, que no se encuentren publicados en otras revistas ni en otros idiomas. Así mismo, el mismo artículo no podrá ser presentado en otras revistas mientras dure el proceso de evaluación.

\section{Envío y presentación de originales}

Los artículos se enviarán exclusivamente a través del correo electrónico a la dirección pantarei@um.es. Los textos serán enviados en formato DOC y las imágenes en formato JPEG o TIFF, y con un tamaño mínimo de 2000 px. Éstas no aparecerán incorporadas en el texto, sino enviadas en archivo aparte y correctamente numeradas según su posición en el texto. Junto al trabajo, se rellenará y enviará un documento aparte en el que se especifiquen los datos del autor siguiendo el modelo disponible en la página Web de la revista.

Para la redacción de los trabajos se tendrá en cuenta el Manual de la American Psychological Association, en su sexta edición. La extensión máxima de los trabajos será de 30 páginas. La tipografía será Arial 11, con interlineado sencillo y sin espacio alguno entre párrafos. El texto deberá ir justificado a ambos márgenes y sin sangría en los primeros párrafos. Los márgenes serán de $2,50 \mathrm{~cm}$. En los casos en los que fuera necesario incorporar notas, éstas irán a pie de página, enumeradas consecutivamente, con tipografía Arial 10, interlineado sencillo y justificadas a ambos márgenes.

Una información más detallada se encuentra disponible en la página http://www.um.es/cepoat/ pantarei.

\section{Proceso de valoración y evaluación}

Una vez recibidos los trabajos, la Revista realizará una primera valoración. Si el trabajo enviado se ajusta a las normas de presentación propuestas, la temática es coincidente con la línea editorial de la revista y posee la calidad científica necesaria, será remitido al consejo asesor para una primera evaluación. Si no es así en este primer paso se puede rechazar directamente los documentos que incumplan claramente la línea editorial.

Será el Consejo Asesor quien indique a la revista la originalidad, relevancia, estructura, redacción, aparato bibliográfico, etc. del trabajo enviado y, para ello, se designará a dos revisores expertos externos que evaluarán cada uno de los trabajos, que pueden formar parte (o no) de este Consejo Asesor. La selección de los revisores se ajustará a la temática y características metodológicas del trabajo. El nombre y filiación de los autores serán eliminados del trabajo para su revisión, así como los revisores actuarán de manera anónima y confidencial.

Los revisores deberán rellenar un informe de evaluación que centrará su atención en aspectos tales como características formales, originalidad y novedad de los trabajos, relevancia de las propuestas y los resultados, calidad metodológica y validez científica.

Una vez terminado el proceso se decidirá la aceptación o no de los mismos y su publicación en el número que sea pertinente, así como las modificaciones susceptibles de ser realizadas para su final publicación. Dicha notificación se enviará únicamente por correo electrónico, en un plazo máximo de seis meses. 


\section{Publishing rules}

The author is committed to submit original papers not having been published in other reviews or in other languages. In this way, it is not allowed for the same paper to be presented in other reviews during the evaluation process.

\section{Submission and presentation of originals}

The articles will be exclusively submitted by email to pantarei@um.es. The texts will be submitted in DOC format and the images in JPEG or TIFF format, and with a minimum size of 2000 px. Images will not be integrated in the text but sent in another file and properly numbered according to their position in the text. Attached to the paper, a document will be filled out and sent where the author's data will be specified following the model available on the website.

The sixth edition of the Manual of the American Psychological Association will be taken into account for the writing of the papers. The length of the papers must not exceed 30 pages. Typography will be Arial 11 , with simple line spacing and no space between paragraphs. The text must be justified on both margins without indentation in the first paragraphs. Margins size will be $2.50 \mathrm{~cm}$. Where it could be necessary the incorporation of notes, they will be at the bottom of the page, consecutively numbered with typography Arial 10, simple line spacing and justified on both margins.

More detailed information is available on the website: http://www.um.es/cepoat/pantarei.

\section{Examination and assessment process}

The Journal will submit the papers to a first examination once received. If the paper follows the presentation guidelines, the subject agrees with the editorial line of this journal, and possess the scientific quality required, it will be sent to the advisory council for a first assessment. If not, the documents which clearly fail to complete the editorial line may be rejected straightaway in this first step.

The Advisory Council will indicate the originality, relevance, structure, writing, bibliography, etc. of the text to the journal; for this purpose, two outside experts will be designated to review the papers; these experts can be (or not) part of this Advisory Council. The selection of the experts will adjust to the subject and methodological characteristics of the paper. Name and affiliation of the author will be eliminated from the text for its review, in this way experts will act anonymously and confidentially.

The experts will fill out an assessment report which will focus on aspects such as formal characteristics, originality and novelty of the papers, relevance and results of the proposal, methodological quality and scientific validity.

Once the process is finished, the acceptance or not of the papers and its publication in the corresponding edition will be decided, as well as the modifications that may be done for its final publication. This notification will be sent by email within 6 months maximum. 


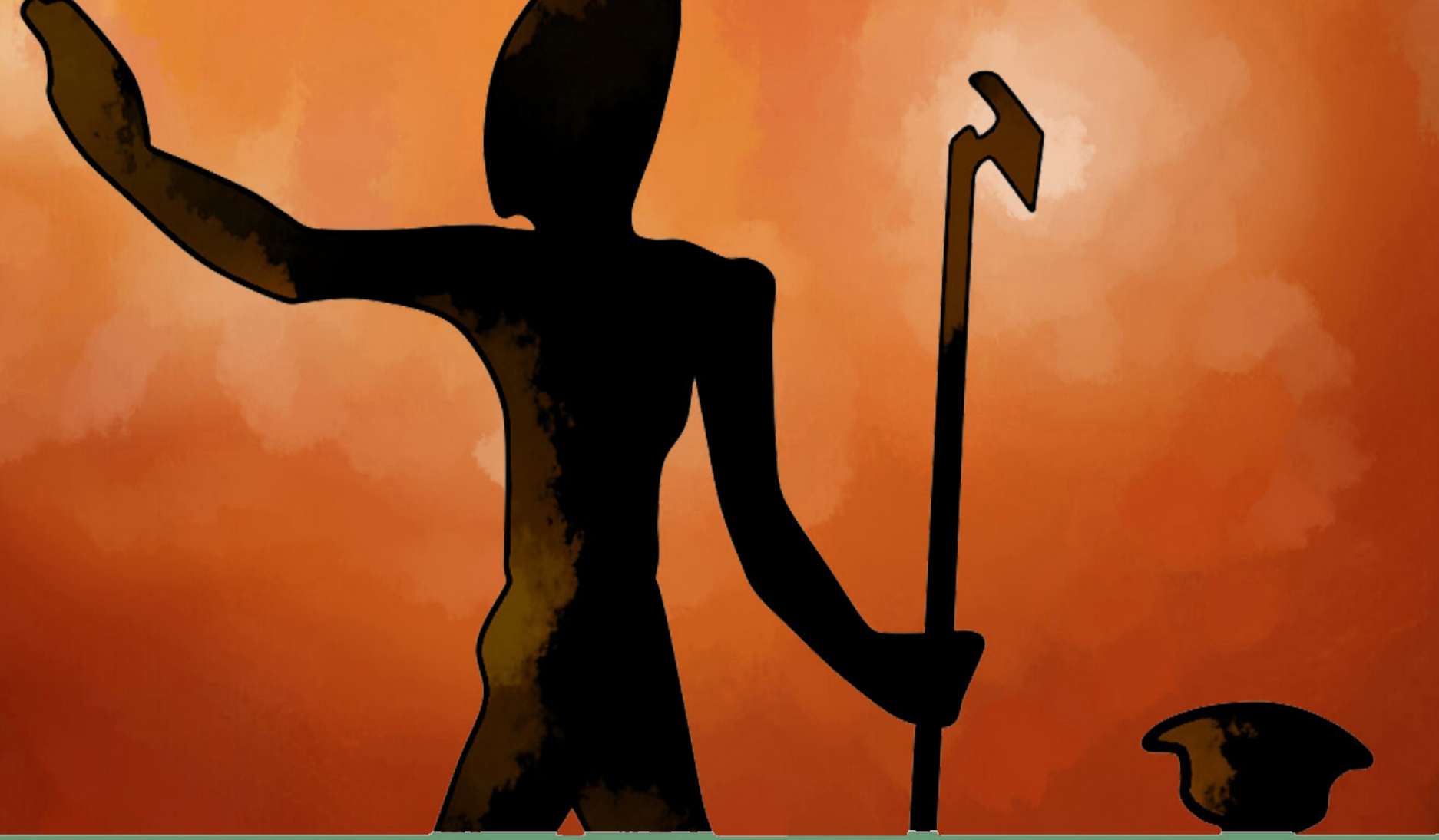

\section{cepot}

UNIVERSIDADD DE MURCIA

centro de estudios del

próximo oriente y la

antigüedad tardía 